\title{
MLCC Solder Joint Property with Vacuum and Hot Air Reflow Soldering Processes
}

\author{
진공 및 열풍 리플로우 솔더링 접합공정에 따른 MLCC 접합특성 \\ Won Sik Hong*, ${ }^{*}$ Mi-Song Kim*, and Myeongin Kim* \\ *Electronic Convergence Materials \& Device Research Center, Korea Electronics Technology Institute, \\ Seongnam, 13509, Korea
}

†Corresponding author: wshong@keti.re.kr

(Received July 11, 2021; Revised July 22, 2021; Accepted August 2, 2021)

\begin{abstract}
After the joining of small 1005 and 0603 multilayer ceramic capacitor (MLCC) components for a semiconductor package using Type 4 (T4) and Type 7 (T7) Sn-3.0Ag-0.5Cu (SAC305), T4 Sn-1.0Ag-0.5Cu (SAC105), and T4 $\mathrm{Sn}-0.3 \mathrm{Ag}-0.7 \mathrm{Cu}$ (SAC0307) solder pastes, the differences between hot air reflow and vacuum soldering processes were compared in terms of void content, shear strength, and microstructure. Results showed that the hot air reflow soldering process exhibited a stable joint with a void content of $5 \%$ or less, and the vacuum soldering condition significantly reduced the void content of the solder joint as the soldering proceeded in a vacuum state. The shear strength of the SAC305 solder joint with the same powder particle size was measured to be greater for the shear strength of the vacuum soldered joint as compared to the reflow process. The vacuum soldering process was effective in removing voids during the void joining process and contributed to an improved joint strength of the solder joint by reducing the void content. When the same soldering process was applied using the 1005 MLCC chip component, the bonding strength of the T4 SAC305 solder was slightly higher than those of the SAC105 and SAC0307 solders. However, the overall initial bonding strengths were similar. The e ffects of Ag content within 0.3-3.0 wt $\%$ on the initial bonding strengths of the solders were judged to be the same. Diverse $\mathrm{Cu}_{6} \mathrm{Sn}_{5}, \mathrm{Ag}_{3} \mathrm{Sn},(\mathrm{Ni}, \mathrm{Cu}, \mathrm{Pd})_{3} \mathrm{Sn}_{4}$, $\left(\mathrm{Cu}, \mathrm{Ni}_{6}\right)_{6} \mathrm{Sn}_{5}, \mathrm{NiP}$, and $\mathrm{Ni}_{3} \mathrm{P}$ intermetalli ccompounds (IMCs) were formed at the interfaces between the electroless nickel/electroless palladium/immersion gold finish substrate and SAC solder joint. The IMC types were constant regardless of Ag content and solder type, and the IMCs contributed to the initial solder joint strength.
\end{abstract}

Key Words: Multi-layer-ceramic capacitor (MLCC), Solder joint, Type 7 solder, Vacuum soldering, Reflow

\section{Introduction}

High memory speed is an essential requirement for implementation of next-generation smart devices and network servers, and in order to increase the memory speed, the number of bumps in semiconductor devices needs to be increased, which leads to an exponential increase in the number of bump junctions. Furthermore, with the increase in the number of bumps, the finer pitch between bumps is required, calling for packaging technology with ultrafine bump pitch $\leq 100 \mu^{1-5)}$. Implementation of fine pitch joints is not achieved by a single technology but requires combination of core technologies in plating, bonding, and molding. However, contrary to the world-leading position of domestic technology in fabrication of memory semiconductors and multilayer ceramic capacitors (MLCC), the key components of electronic devices, the rate of localization in the areas of plating materials, process equipment and MLCC electrode materials used in semiconductor wiring process and MLCC fabrication is low.

In order to achieve localization in product development and commercial application, assurance in product performance and reliability in high durability is instrumental for domestic semiconductor packaging com- 
ponents and embedded passive components such as MLCC. With the recent increase in the use of mobile devices and variety of application programs, the use of application processor (AP) modules for concurrent processing of multiple functions has shown a sharp increase $^{4,5)}$. The number of $\mathrm{I} / \mathrm{O}$ systems is rapidly increasing in AP modules, and passive components such as MLCC are embedded in the modules. At the same time, the overall trend is that AP modules used in mobile devices are becoming lighter, thinner, and smaller, and the size of passive components such as MLCCs embedded in the modules is also decreasing from 1005 to ultrasmall MLCC such as 0603 or 0402 . For bonding of Si semiconductor devices with more than 1,000 bumps, thermal compression bonding (TC bonding) or flip chip bonding is used in which bonding is performed with the application of heat and pressure. On the other hand, in the case of ultra-small MLCC components, which are passive components, modularization is implemented through the hot air reflow soldering process, a typical soldering process. However, in the case of hot air reflow soldering process, the area of the MLCC electrode is decreasing in line with the trend of the miniaturization of parts, leading to degradation in long-term bonding durability due to void formation in the MLCC solder joints.

Therefore, in this study, using the ultra-small MLCC components of 1005 and 0603 actually mounted in the semiconductor packages and the ternary $\mathrm{Pb}$-free solder paste of $\mathrm{Sn}-\mathrm{Ag}-\mathrm{Cu}$ with the powder particle sizes of Type 4 (T4) and Type 7 (T7), optimization of soldering process was performed for the small passive components with the void content of the solder joints within $3.0 \%$. In order to minimize the void content of the solder joints, the conventional hot air reflow soldering and vacuum soldering processes were respectively applied to optimize the process for minimization of void defects in the joint.

\section{Experimental method}

\subsection{Substrates and MLCC components for semi- conductor packaging}

As shown in Fig. 1, a substrate made of bismaleimide triazine (BT), a type of thermosetting polyimide resin, was used in the experiment for the flip-chip chipscale-package (FCCSP) substrate. The BT material is an insulator mainly containing bismaleimide and triazine resin. BT resin is a plastic material, mainly used in printed circuit boards bridging semiconductors (chips) in smartphones and PCs with its excellent heat resistance. The thickness of the BT substrate was 0.3 $\mathrm{mm}$, and the surface of the pad of the BT substrate was treated with electroless nickel/ electroless palladium/ immersion-gold (ENEPIG) plating. The thickness of the surface treatment was 3-8 $\mu \mathrm{m}$ for $\mathrm{Ni}, 0.05-0.15 \mu \mathrm{m}$ for $\mathrm{Pd}$, and 0.05-0.15 $\mu \mathrm{m}$ for $\mathrm{Au}$.

Fig. 2 shows an image of the MICC components
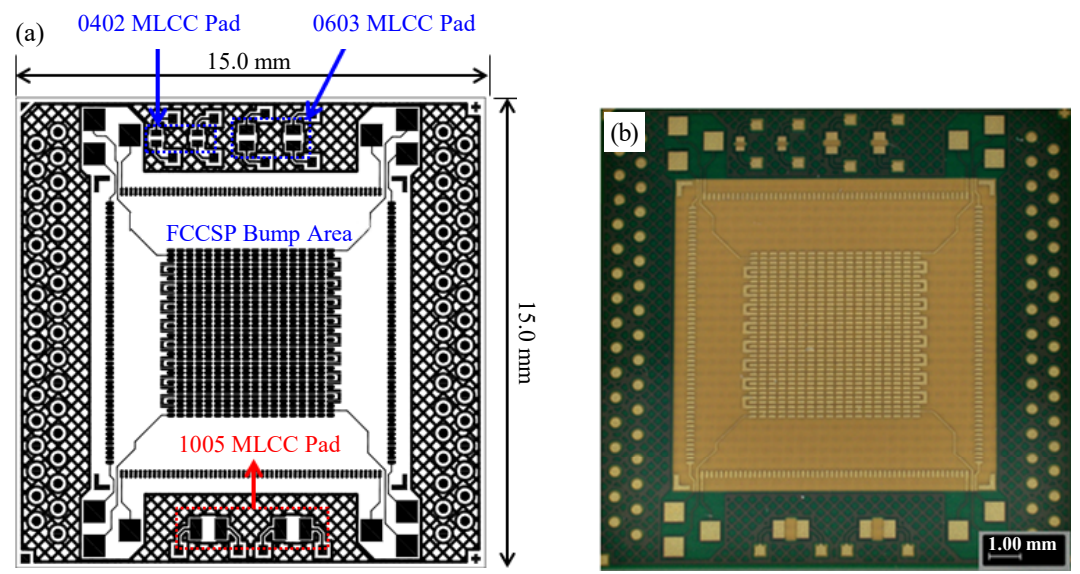

Fig. 1 Overview of flip-chip chip scale packaging, (a) schematic drawing and (b) optical micrograph of BT substrate

(a)

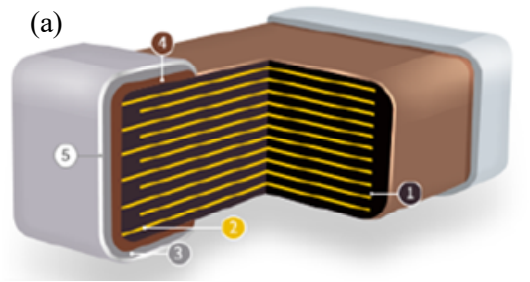

(b)

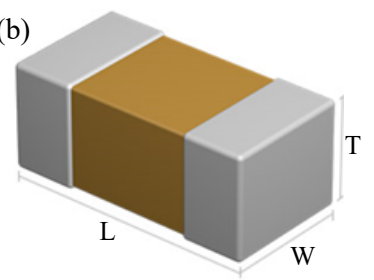

Fig. 2 Schematics of MLCC components ${ }^{6}$, (a) sectional view and (b) 3-dimensional image 
mounted on the BT substrate. The 1005 MLCC components $(1.00(\mathrm{~L}) \times 0.50(\mathrm{~W}) \times 0.50(\mathrm{t}) \mathrm{mm}, 2.2-22 \mu \mathrm{F})$ and $0603 \operatorname{MLCC}(0.60(\mathrm{~L}) \times 0.30)(\mathrm{W}) \times 0.33(\mathrm{t}) \mathrm{mm}, 1-4 \mu \mathrm{F})$ components manufactured by Samsung Electro-Mechanics were used (4). For the plating of terminal electrodes of MLCC components, Ni electro-underlayer-coating and Sn plating were applied. The widths of the electrodes plated on the 0603 and 1005 MLCC terminals were $0.15 \pm 0.05 \mathrm{~mm}$ and $0.25 \pm 0.05 \mathrm{~mm}$, respectively.

\subsection{Pb-free solder paste and printing process}

For comparison of MLCC bonding properties with different powder sizes, four types of pastes were used for the $\mathrm{Pb}$-free solders in real MLCC components as shown in Table 1. The four types of solder paste used with the Pb-free solder were: T4 and T7 Sn-3.0Ag$0.5 \mathrm{Cu}$ (SAC305), T4 Sn-1.0Ag-0.5Cu (SAC105) and T4 Sn-0.3Ag-0.7Cu (SAC0307). As shown in Fig. 3, the difference between the powder sizes of Type 4 and Type 7 solder paste can be seen in the SEM (Scanning electron microscope) micrographs. Since the powder of Type 7 solder paste is very fine from the image, it is judged to be more suitable for fine pitch solder paste printing.

The solder paste printing was performed with an area ratio aperture of $100 \%$ using a metal mask made of 100 $\mu \mathrm{m}$ thick SUS material. After the printing, the printing status of the solder paste was examined using a 30x optical microscope.

\subsection{Hot air reflow soldering and vacuum soldering}

As for the MCC soldering processes performed in the experiment, hot air reflow soldering (Heller Co. Ltd., 1809UL, USA) and Vacuum soldering (Unitemp Co. Ltd., RSS-210-S, Germany) were applied for optimization of soldering process in order to achieve minimization of void defects in the substrate and MLCC joints. Hot air reflow soldering was performed for $8 \mathrm{mi}-$ nutes in total with the preheating temperature of $150-160{ }^{\circ} \mathrm{C}$ and a maximum temperature of $245-250{ }^{\circ} \mathrm{C}$ for 30s. For vacuum soldering bonding, the bonding was performed for a total of $17.5 \mathrm{~min}$ with the preheating temperature of $150^{\circ} \mathrm{C}$ for $120 \mathrm{~s}$ and the maximum heating temperature at main heating section at $255^{\circ} \mathrm{C}$ for $180 \mathrm{~s}$ with the degree of vacuum at $5 \mathrm{hPa}$ (3.75 torr).

\subsection{Measurement of void content at solder joints and shear strength test}

The void content measurement of the solder joints was

Table 1 Chemical composition, type and powder size of $\mathrm{Pb}$-free solder pastes

\begin{tabular}{|c|c|c|c|}
\hline Solder alloy composition & Solder paste type & Powder size $(\mu \mathrm{m})$ & Manufacturer \\
\hline \multirow{2}{*}{ Sn-3.0Ag-0.5Cu (SAC305) } & $\mathrm{T} 4$ & $20-38$ & \multirow{2}{*}{$\begin{array}{l}\text { MK Electron Co., Ltd. } \\
\text { (Korea) }\end{array}$} \\
\hline & $\mathrm{T} 7$ & $5-15$ & \\
\hline Sn-1.0Ag-0.5Cu (SAC105) & \multirow{2}{*}{$\mathrm{T} 4$} & \multirow{2}{*}{$20-38$} & \multirow{2}{*}{$\begin{array}{l}\text { Ecojoin Co., Ltd. } \\
\text { (Korea) }\end{array}$} \\
\hline Sn-0.3Ag-0.7Cu (SAC0307) & & & \\
\hline
\end{tabular}

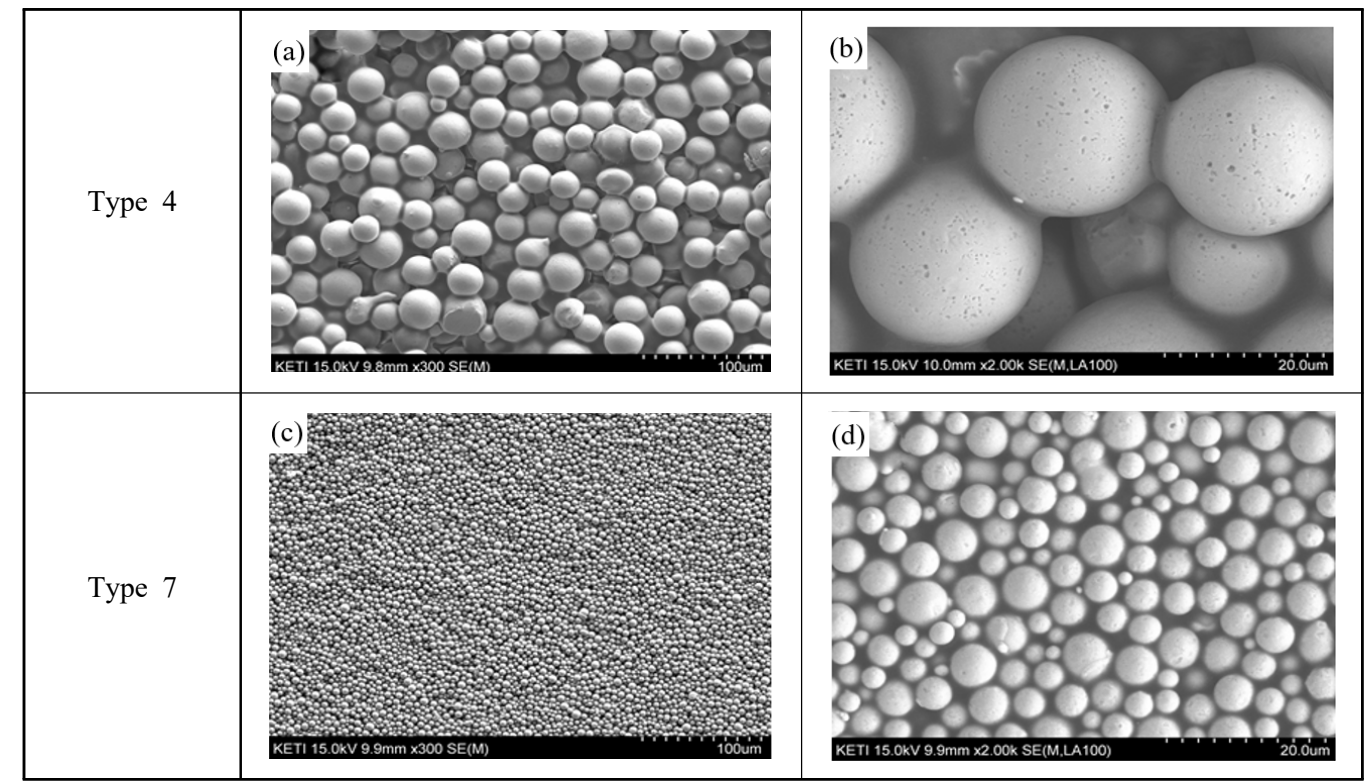

Fig. 3 SEM micrographs of (a,b) Type 4 and (c,d) Type 7 solder paste of Sn-3.0Ag-0.5Cu solder alloy 
performed based on the area of voids existing within the joint area of the solder, and the void measurement was performed using X-ray non-destructive microscope (Resolution, X-Tek Co. Ltd., UK). Dage 4000 (Nordson Co., Ltd., USA) was used for measurement of the joint strength of the solder joints in MLCC chip components, and shear strength test was performed on the MLCC solder joints. In the shear strength test, the test was performed under the conditions of test speed at $167 \mu \mathrm{m} / \mathrm{sec}$ and the height of the test fixture at $50 \mu \mathrm{m}$ from the substrate, and the bonding strength was comparatively analyzed with respect to the type of solder paste and the type of soldering process used.

\section{Experimental Results}

\subsection{Void content of MLCC solder joints}

For MLCC soldering, as shown in Fig. 5, the solder paste was printed on the pad surface of the substrate and the printing state was observed using an optical microscope. After the solder paste was printed on the substrate pad surface, slumps were well formed and maintained. After mounting the MLCC chip on the printed solder paste, the bonding process was performed using reflow soldering and vacuum soldering processes. After the soldering, the observation of the 1005 MLCC and 0603 MLCC joints showed good bonding state of solder fillets as can be seen in Figs. 6 and 7. Fig. 8 shows the comparison of the void content in the joint with different types of solder paste and the soldering processes. The void content $(\%)$ of the 1005 MLCC joint bonded by the hot air reflow soldering process was about 1.6-4.3\%, and that of the 0603 chip was about $1.1-3.7 \%$. On the other hand, the void content of the 1005 MLCC joint bonded by the vacuum soldering process was $0.1-0.7 \%$, and that of the 0603 chip was $0.5-1.5 \%$. Although the result from the conventional hot air reflow soldering process showed a stable joint void content of less than $5 \%$, the result confirmed that the void content of the joint was significantly reduced with the application of vacuum soldering. As shown in Fig. 4(d), in the vacuum soldering process, a vacuum state is maintained in the main heating section of the temperature profile, which led to the increase in the void fluidity inside the molten solder and decrease in the voids in the solder joints. In general, as the size of the component or the area of the joint becomes smaller, the void content within the molten solder tends to increase due to the application of the greater surface tension on the surface in contact with the pad of the substrate or the solder. For this reason, the result showed that the voids that were not completely removed in the conventional reflow process were effectively removed int eh vacuum soldering
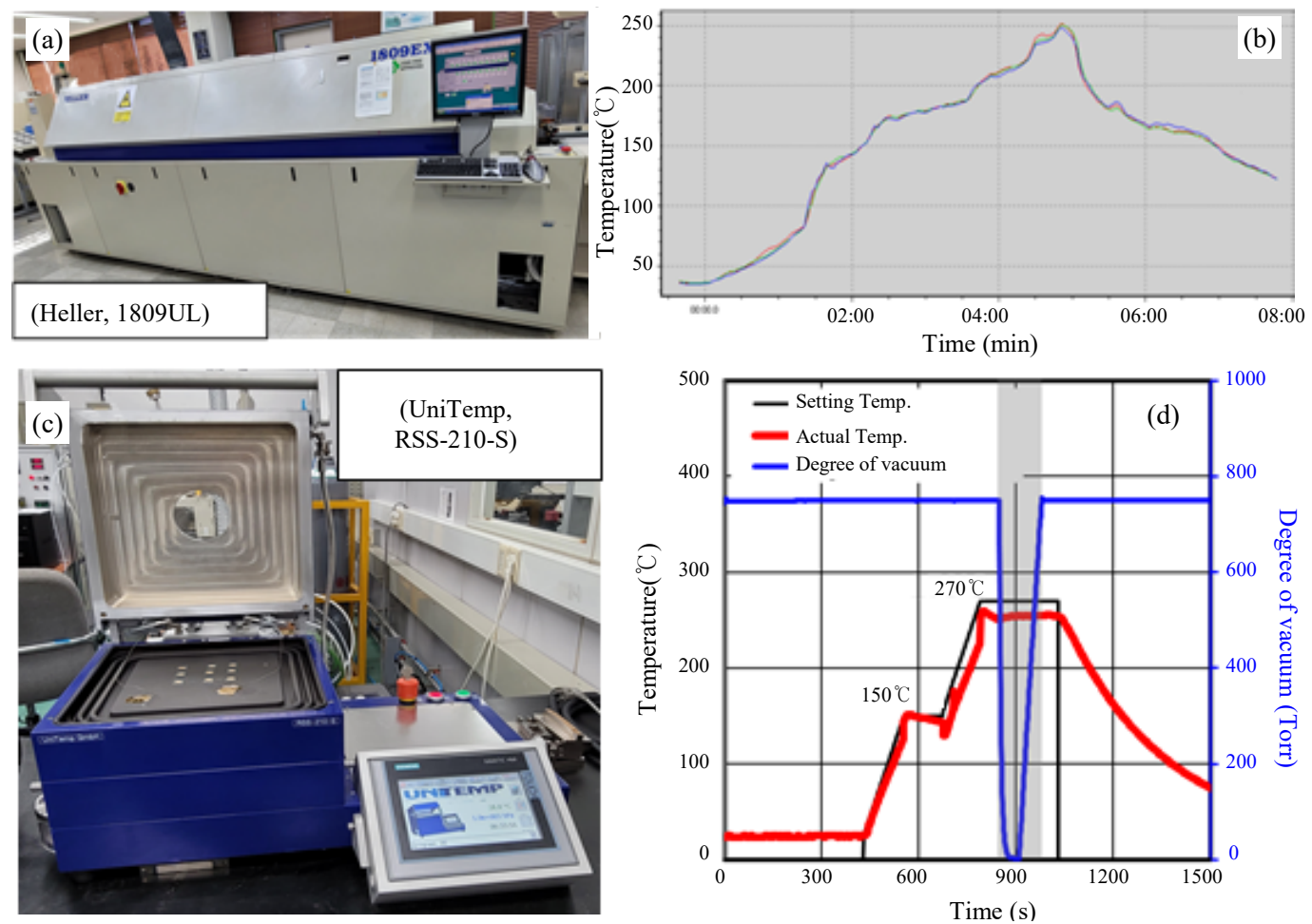

Fig. 4 Photographs of (a) hot air reflow machine and (b) temperature profile, and (c) vacuum soldering machine and (d) temperature and vacuum profile 


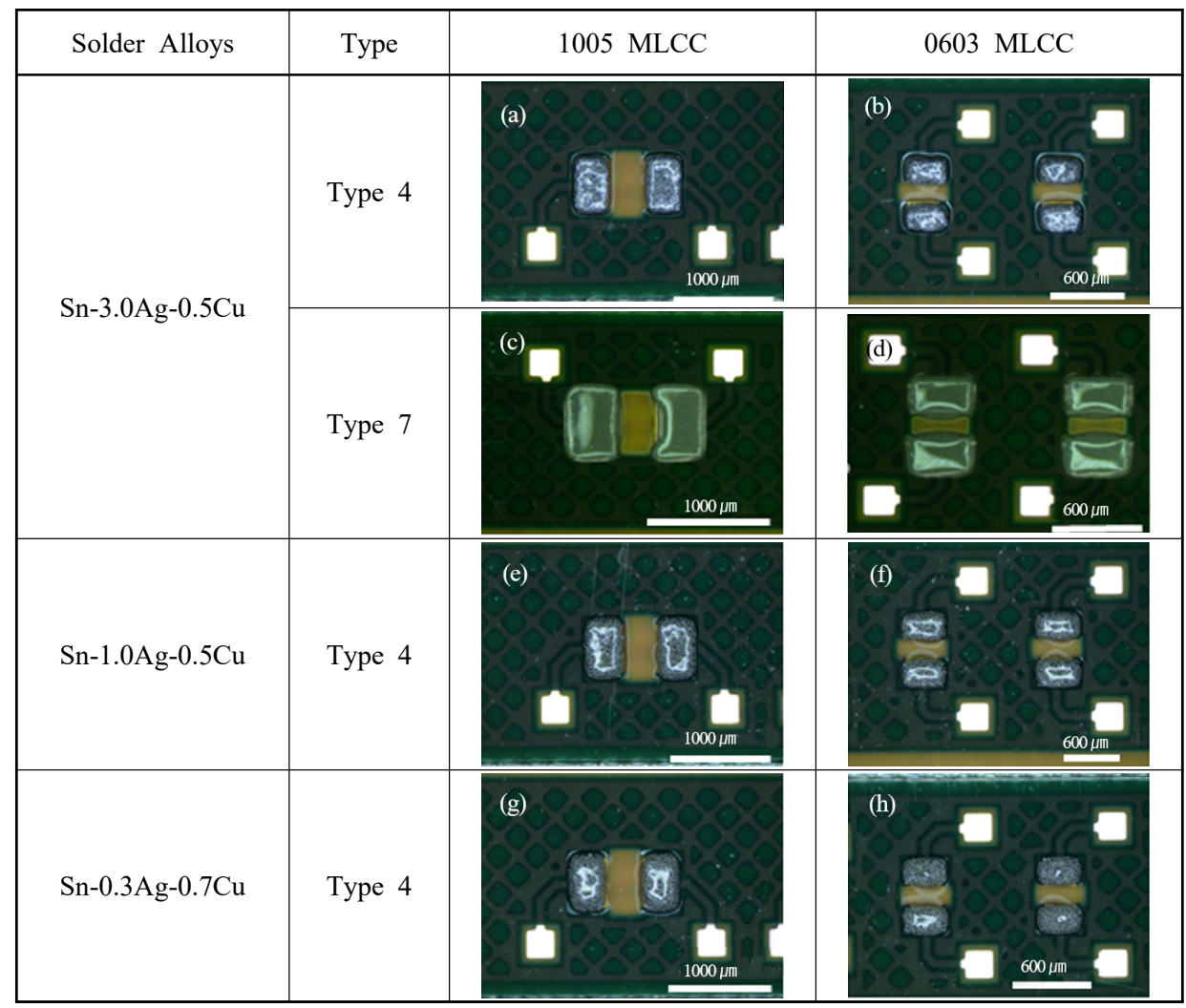

Fig. 5 Optical micrographs after printing process with various solder alloys and types, (a-d) Sn-3.0Ag-0.5Cu, (e,f) $\mathrm{Sn}-1.0 \mathrm{Ag}-0.5 \mathrm{Cu}$ and $(\mathrm{g}-\mathrm{h}) \mathrm{Sn}-0.3 \mathrm{Ag}-0.7 \mathrm{Cu}$ solder pastes

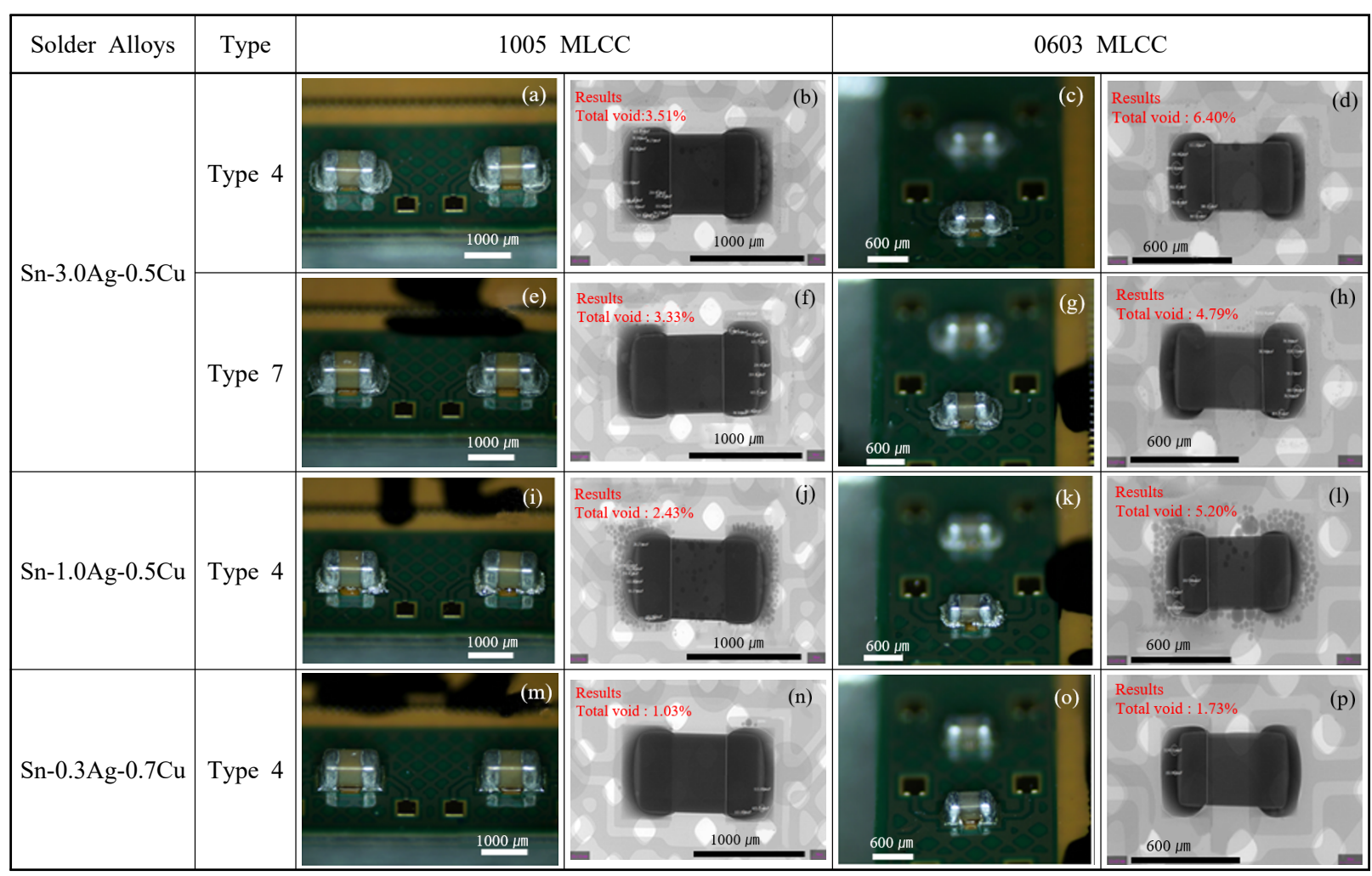

Fig. 6 Optical micrographs and X-ray non-destructive void content of 1005 and 0603 MLCC solder joints with (a-h) Sn-3.0Ag-0.5Cu, (i-1) Sn-1.0Ag-0.5Cu and (m-p) Sn-0.3Ag-0.7Cu solder alloys using by hot air reflow soldering process 


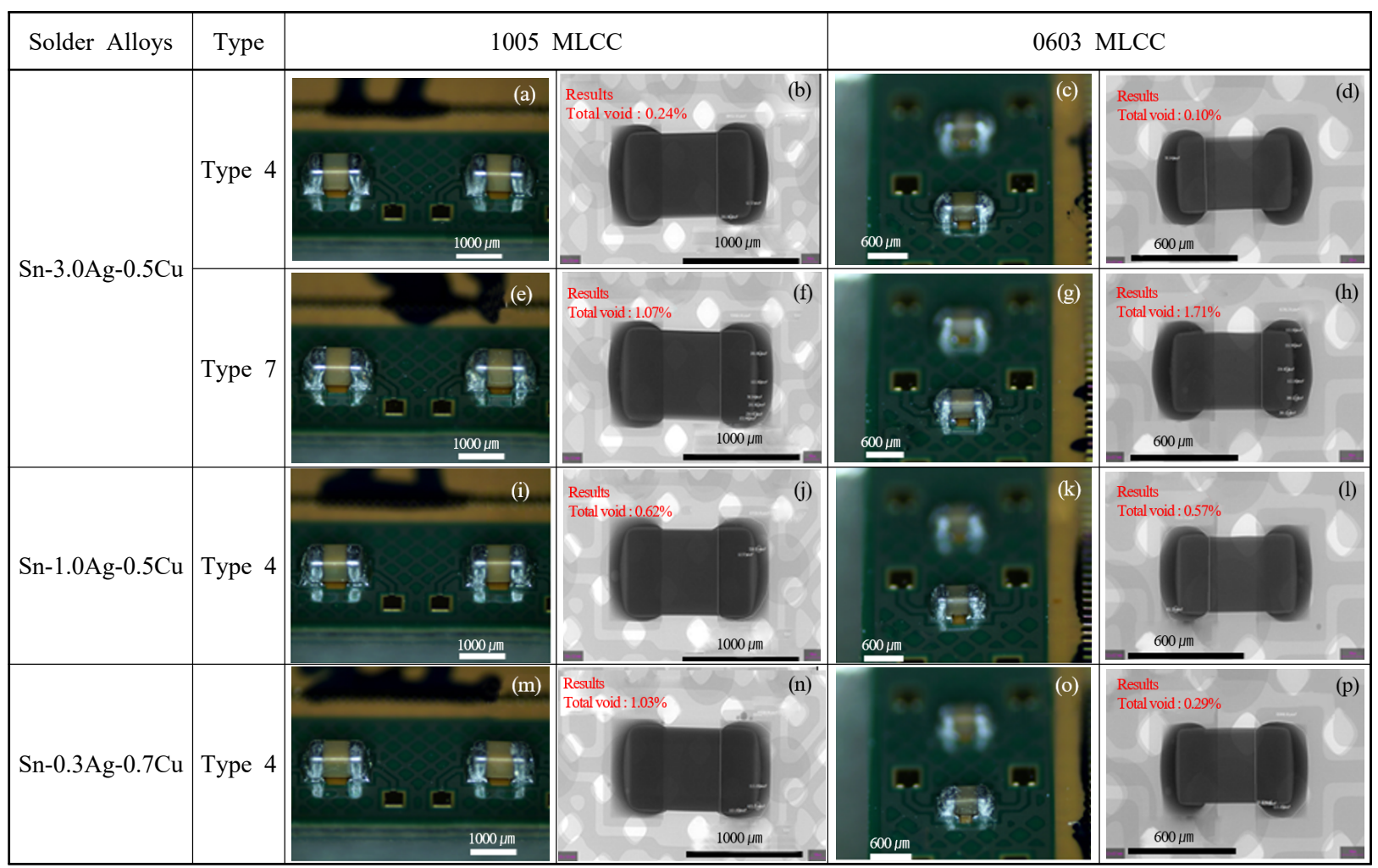

Fig. 7 Optical micrographs and X-ray non-destructive void content of 1005 and 0603 MLCC solder joints with (a-h) $\mathrm{Sn}-3.0 \mathrm{Ag}-0.5 \mathrm{Cu},(\mathrm{i}-1) \mathrm{Sn}-1.0 \mathrm{Ag}-0.5 \mathrm{Cu}$ and $(\mathrm{m}-\mathrm{p}) \mathrm{Sn}-0.3 \mathrm{Ag}-0.7 \mathrm{Cu}$ solder alloys using by vacuum soldering process

process. Also, in the case of the same SAC305 solder, the use of T4 and T7 paste showed the result of almost similar void content, but in the case of 1005 MLCC chip, the use of $\mathrm{T} 7$ paste showed rather higher void content. This is considered to be the result of applying the same temperature profile to the $\mathrm{T} 4$ and $\mathrm{T} 7$ solder pastes, and it is judged that with the decrease in the powder size of the solder paste, applying different temperature condition from the existing T4 is more appropriate. In both SAC105 and SAC0307 solders with the powder size of $\mathrm{T} 4$, a similar level of void content at less than $2 \%$ was observed.

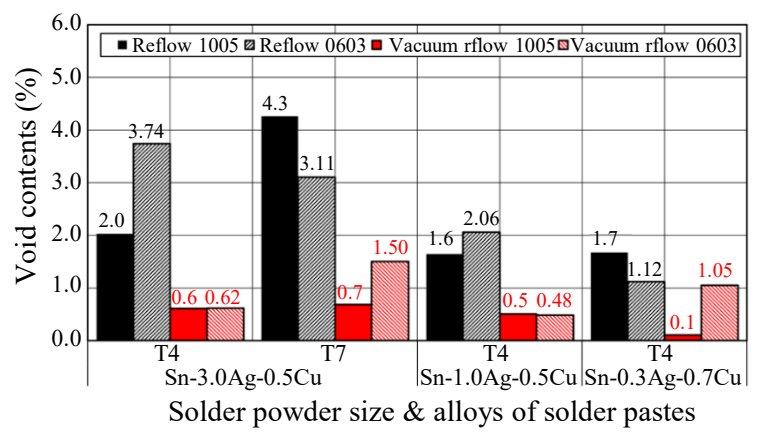

Fig. 8 Void content comparison between hot air reflow and vacuum soldering process with various alloy compositions and powder size of the solder pastes

\subsection{Bonding strength of MLCC solder joints}

Fig. 9 shows the average value of bonding strength for four identical 1005 and 0603 MLCC solder joints, respectively, bonded by the conventional hot air reflow soldering and the proposed vacuum soldering processes. The values of shear strength of hot air reflow soldering and vacuum soldering processes using the same T4 SAC305 solder and 1005 MLCC were $1.06 \pm 0.08 \mathrm{kgf}$ and $1.73 \pm 0.11 \mathrm{kgf}$, respectively, and the shear strength for $0603 \mathrm{MLCC}$ was $0.64 \pm 0.04 \mathrm{kgf}$ and $0.70 \pm 0.02 \mathrm{kgf}$, respectively, for each type of process. For the T7 SAC305 solder, the shear strength of the 1005 and 0603

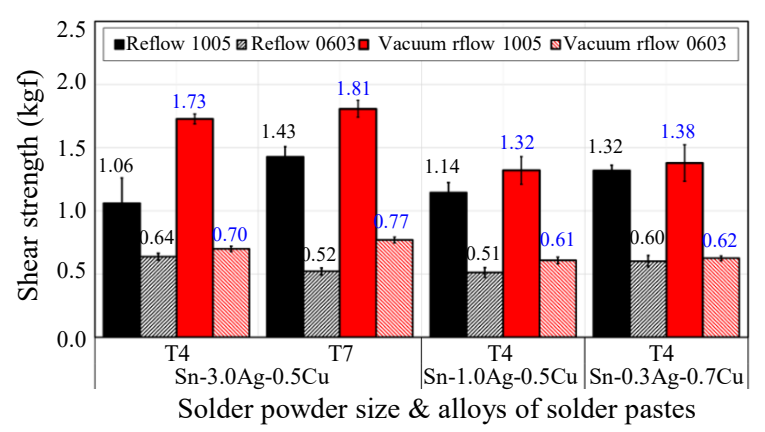

Fig. 9 Shear strength comparison between hot air reflow and vacuum soldering process with various alloy compositions and powder size of the solder pastes 
MLCC solder joints were measured at $1.43 \pm 0.09 \mathrm{kgf}$ (Reflow) and $1.81 \pm 0.13 \mathrm{kgf}$ (Vacuum), and $0.52 \pm 0.08$ kgf (Reflow) and $0.77 \pm 0.03 \mathrm{kgf}$ (Vacuum), respectively. Considering that the standard deviation for the shear strength values of all components was around $\pm 0.1 \mathrm{kgf}$ when measured irrespective of the soldering process, the results indicate that the difference in bonding strength occurred due to the difference in the bonding process. The result from vacuum soldering showed higher bonding strength than that of the hot air reflow soldering process.

Comparing the shear strength according to the difference in T4 and T7 powder sizes in the same SAC305 solder, the results from the hot air reflow soldering were 1.06 and $1.43 \mathrm{kgf}$, respectively, and the results from the vacuum soldering process were measured at 1.73 and $1.81 \mathrm{kgf}$, respectively. However, when the same bonding process is applied with the same T4 powder size, the initial bonding strength of the SAC305 solder shows similar values regardless of the Ag content. From these results, it can be seen that when the solder of the same composition was used, application of vacuum soldering exhibited greater bonding strength that the case with the hot air reflow soldering. Also, in the same composition of SAC305, T7 with finer powder consistency showed higher bonding strength than T4.

Also, comparing the shear strength of T4 SAC305, T4 SAC105 and T4 SAC0307, the values of 1005 chip were 1.06-1.32 kgf (Reflow) and 1.32-1.73 kgf (Vacuum), and 0603 chip was 0.51-0.64 kgf (Reflow) and 0.61-0.77. kgf (Vacuum), respectively. This indicates that although these were solder with different content of $\mathrm{Ag}$, in terms of the alloy composition of the solder, the bonding strength of the chip component with the same process and the same powder size was more or less the same for all of the SAC305, SAC105 and SAC0307 solders. This indicates that the initial bonding strength of the solder joint shows a similar level within the content range of $0.3-3.0 \mathrm{wt} \%$ of $\mathrm{Ag}$ in the $\mathrm{Sn}-\mathrm{Ag}-\mathrm{Cu}$ eutectic alloy system. According to the results of previous studies by Hong ${ }^{7-9)}$, when the content of $\mathrm{Ag}_{3} \mathrm{Sn}$ in the substrates of SAC305 and SAC0307 solder was compared after 2000 cycles of thermal shock, the $\mathrm{Ag}_{3} \mathrm{Sn}$ content in the SAC0307 solder was smaller. The previous study reported that with the decrease in the Ag content in the solder substrate, the production of primary-Sn increased and consequently, the amount of $\mathrm{Sn}$ to form $\mathrm{Ag}_{3} \mathrm{Sn}$ decreases, leading to the decreased fraction of $\mathrm{Ag}_{3} \mathrm{Sn}$ in SAC0307 solder than in SAC305 solder. In this way, it was reported that finely dispersed $\mathrm{Ag}_{3} \mathrm{Sn}$ contributes to the increase of the initial bonding strength of the solder joint, but when the aging temperature is increased and exposed to high temperature for a long time, the bonding strength of the solder joint is reduced by the growth and coarsening of $\mathrm{Ag}_{3} \mathrm{Sn}^{7-9)}$.

However, in the soldering processes used in this study, greater shear strength was observed in the vacuum soldering process than in the hot air reflow process, and it can be inferred that the vacuum soldering process reduces the void content and contributes to the increase in the bonding strength of the solder joints. The experimental results compare the difference in initial bonding strength, and it is judged that for comparison of long-term reliability of the solder joints, the difference according to alloy composition and powder size should be compared by a thermal shock test.

\subsection{Analysis of solder joint interface}

The images of the sectional view for the T7 SAC305 solder joint with the application of hot air reflow process for 1005 MLCC and 0603 MLCC are presented in Fig. 10 and Fig. 11, respectively. The void content of the solder joint was considerably small, and the figures also confirm that the joint fillets were also well formed. It can be seen that in the solder joint interface between the chip and the substrate, $(\mathrm{Cu}, \mathrm{Ni})_{6} \mathrm{Sn}_{5}$, the intermetallic compound (IMC) was formed. In general, IMCs of $(\mathrm{Cu}, \mathrm{Ni})_{6} \mathrm{Sn}_{5}$ and $(\mathrm{Ni}, \mathrm{Cu})_{3} \mathrm{nSn}_{4}$ are formed in the SAC305 soldering interface that has undergone the surface treatment of Electroless Nickel Immersion Gold (ENIG) or ENEPIG. Also, Ni-P IMCs such as NiP, $\mathrm{Ni3P}$ and Ni3P4 are formed on the interface of Ni plating layer and solder and in the area of solder joint, the formation of $\mathrm{Ag}_{3} \mathrm{Sn}$ and $\mathrm{Cu}_{6} \mathrm{Sn}_{5}$ have been reported 7,8,10-11). In this study, as can be seen in Fig. 9(b-c), the formation of $(\mathrm{Cu}, \mathrm{Ni}, \mathrm{Pd})_{6} \mathrm{Sn}_{5}$ and $(\mathrm{Ni}, \mathrm{Cu}, \mathrm{Pd})_{3} \mathrm{nSn}_{4}$ IMCs was observed in the initial interface after soldering, on the SAC305 solder and ENEPIG joint interface. Fig. 12 shows the SEM micrographs for the sectional analysis of the SAC105 solder joint of 0603 MLCC chip components. In the substrate area of the solder joint fillet, $\mathrm{Cu}_{6} \mathrm{Sn}_{5}$ and $\mathrm{Ag}_{3} \mathrm{Sn}$, the typical IMCs observed in SAC composition were observed. In the MLCC-ENEPIIG substrate joint interface, the formation of $\mathrm{Ni}, \mathrm{Cu}, \mathrm{Pd})_{3} \mathrm{nSn}_{4} \mathrm{IMC}$ was observed. Also, in the case of ENIG-treated surface, Au-Sn compounds are detected in the substrate ${ }^{12)}$. As Au-Sn IMCs, there are various types of IMCs including $\mathrm{AuSn}, \mathrm{Au}_{2} \mathrm{Sn}$, $\mathrm{AuSn}_{2}$, and $\mathrm{AuSn}_{4}$, and a trace amount of needle-shaped $\mathrm{Au}_{2} \mathrm{Sn}$ IMCs was also detected at the joint in Fig. 9(b).

Fig. 13 shows the sectional SEM micrographs of the SAC105 hot air reflow solder joint of 0603 MLCCsubstrate. In the soldering interface of the MLCC electrode area, irregular needle-shaped IMCs of $(\mathrm{Cu}, \mathrm{Ni})_{6} \mathrm{Sn}_{5}$ 


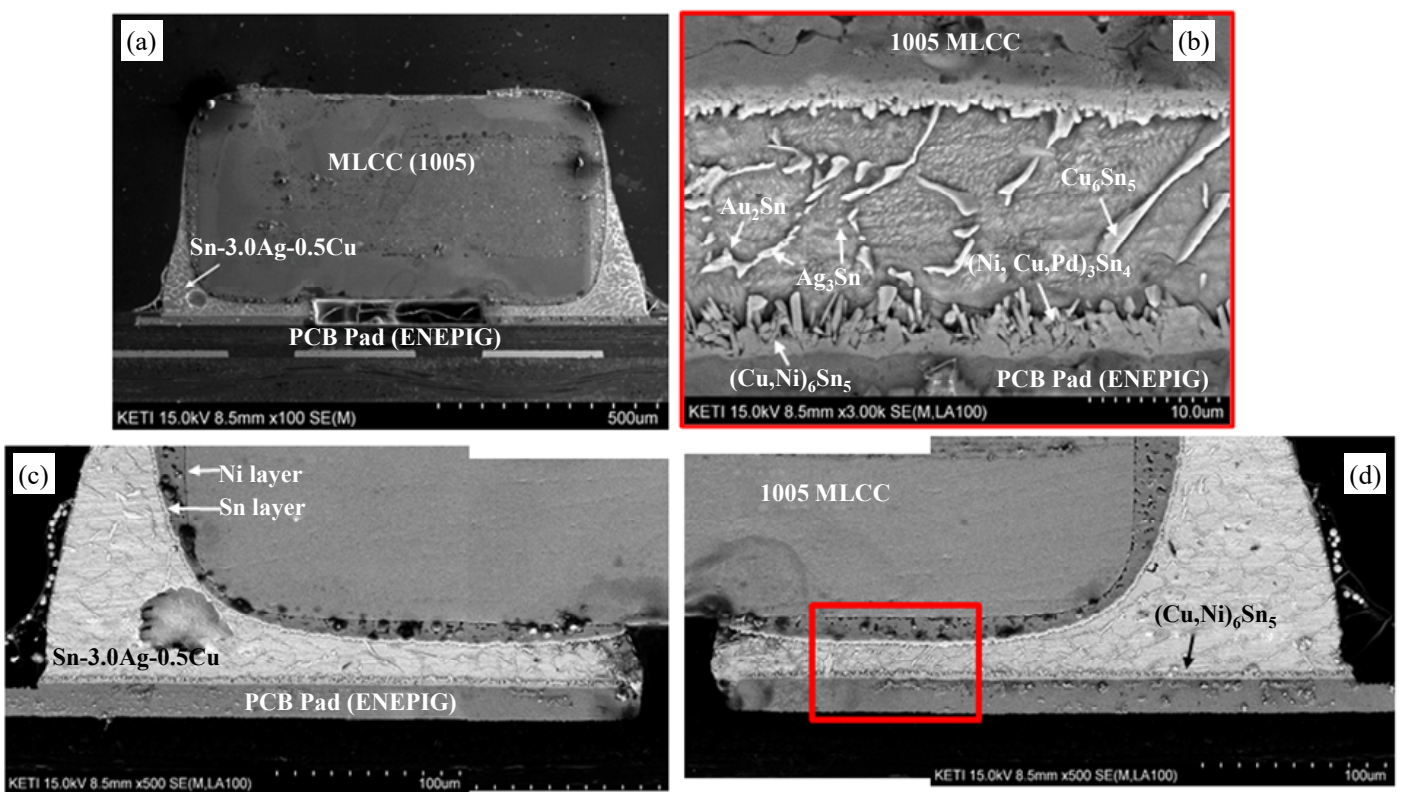

Fig. 10 SEM micrographs of 1005 MLCC solder joint with Type 7 Sn-3.0Ag-0.5Cu solder after hot air reflow soldering
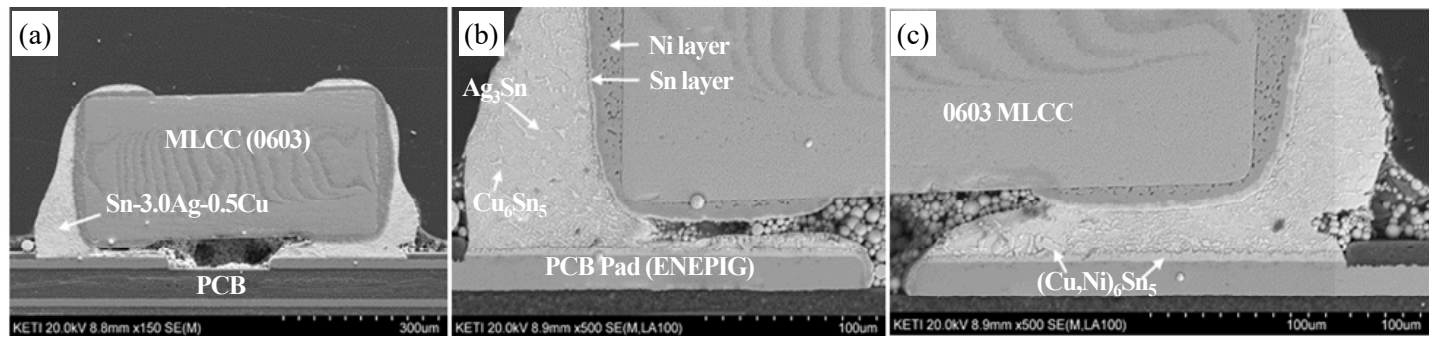

Fig. 11 SEM micrographs of $0603 \mathrm{MLCC}$ solder joint with Type $7 \mathrm{Sn}-3.0 \mathrm{Ag}-0.5 \mathrm{Cu}$ solder after hot air reflow soldering

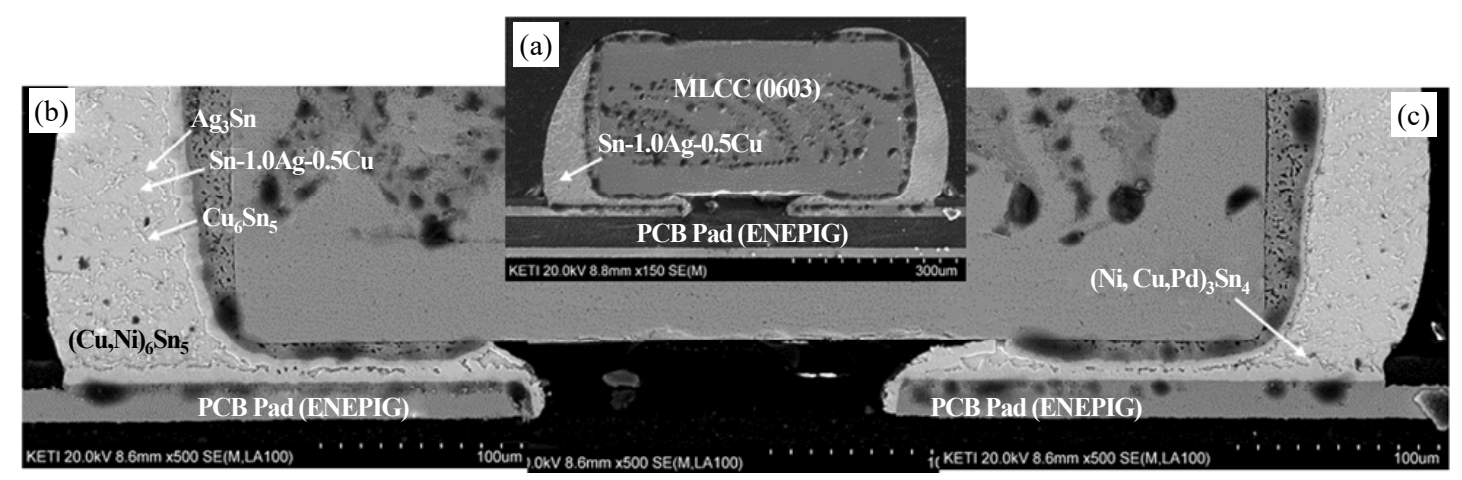

Fig. 12 SEM micrographs of 0603 MLCC solder joint with Type 4 Sn-1.0Ag-0.5Cu solder after vacuum soldering

was formed, and in the junction solder layer, $(\mathrm{Ni}$, $\mathrm{Cu}, \mathrm{Pd})_{3} \mathrm{Sn}_{4}, \mathrm{Ag}_{3} \mathrm{Sn}$, and $\mathrm{Cu}_{6} \mathrm{Sn}_{5}$ IMCs were formed. On the interface of the solder-BT substrate, NiP and $(\mathrm{Cu}, \mathrm{Ni})_{6} \mathrm{Sn}_{5}$ IMCs were observed. Fig. 14 shows the SEM and EDS analysis of the area in which the interface of the solder-BT substrate is mainly formed. In the solder substrate part, the formation of $\mathrm{Cu}_{6} \mathrm{Sn}_{5}, \mathrm{Ag}_{3} \mathrm{Sn}$ and the needle-shaped $(\mathrm{Ni}, \mathrm{Cu}, \mathrm{Pd})_{3} \mathrm{Sn}_{4} \mathrm{IMC}$ was observed, and in the soldering interface of the substrate, the formation of $\mathrm{Ni}, \mathrm{Cu}, \mathrm{Pd})_{3} \mathrm{Sn}_{4},(\mathrm{Cu}, \mathrm{Ni})_{6} \mathrm{Sn}_{5}, \mathrm{NiP}$ and $\mathrm{Ni}_{3} \mathrm{P}$ IMCs was confirmed. It has been reported that when various IMCs are formed on the interface between ENEPIG finish substrate and soldering joint of SAC composition, growth behavior of the IMCs over time affects the long-term reliability of the solder joint $^{7,8,10,11)}$. The various IMCs shown in this study contribute to the improvement of the initial bonding strength, but the types of IMCs produced vary depend- 

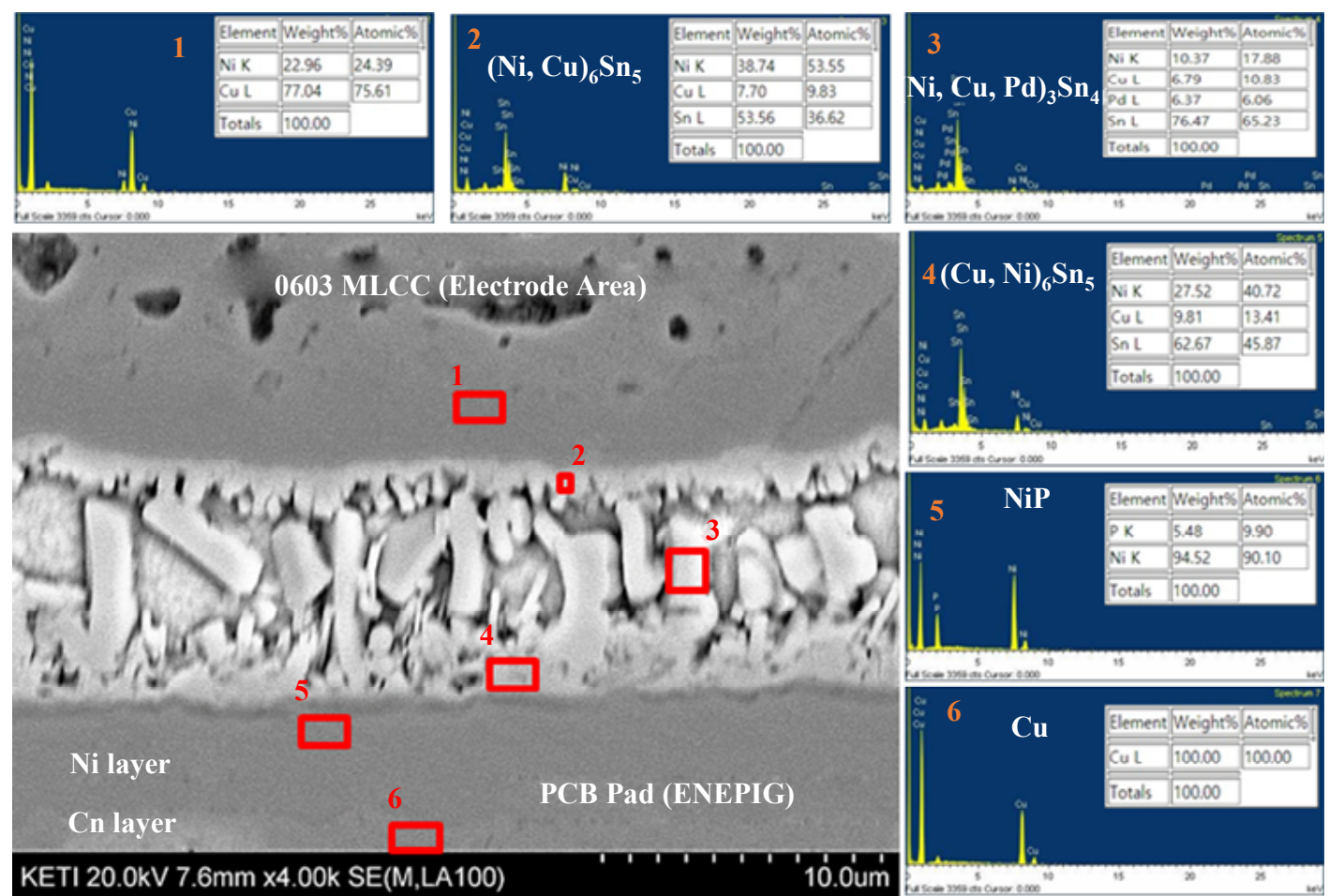

Fig. 13 SEM micrograph and EDS analysis results of 0603 MLCC solder joint between BT substrate and MLCC with Type $4 \mathrm{Sn}-1.0 \mathrm{Ag}-0.5 \mathrm{Cu}$ solder after hot air reflow soldering
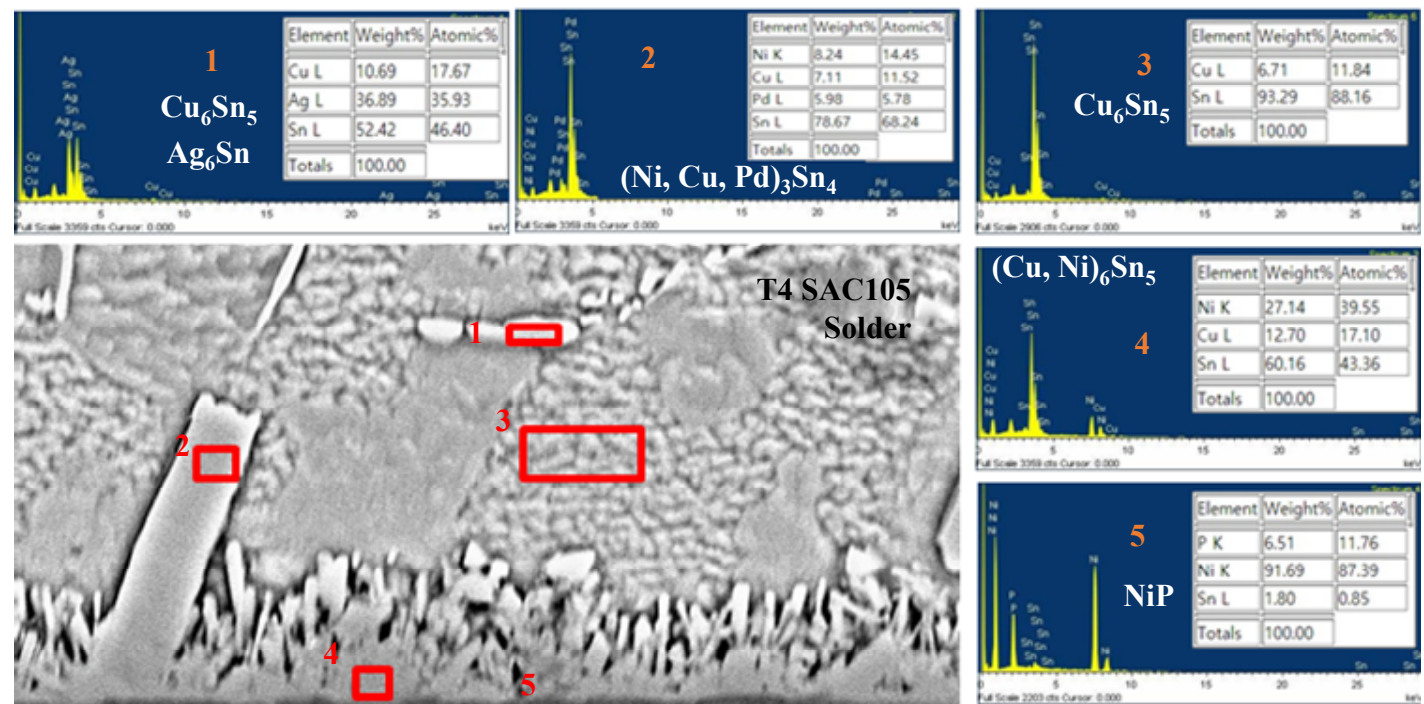

Ni layer

Cu layer

PCB Pad (ENEPIG)

KETI 20.0kV 7.6mm $\times 4.00 \mathrm{~K}$ SE(M,LA100)

10.0'ún

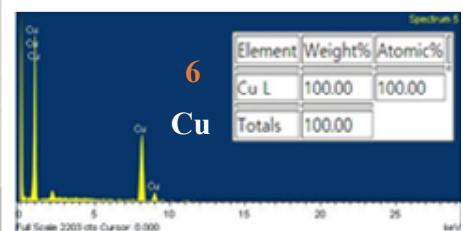

Fig. 14 SEM micrograph and EDS analysis results of 0603 MLCC solder joint between BT substrate and solder interface with Type $4 \mathrm{Sn}-1.0 \mathrm{Ag}-0.5 \mathrm{Cu}$ solder after hot air reflow soldering

ing on the pad surface-treated layers, but almost the same types of IMCs were formed according to the type of the solder and Ag content. However, in the long term, these factors are also thought to induce the degradation in the joints, and therefore, further investigation on the long-term reliability is required. 


\section{Conclusion}

In this study, soldering was performed with 1005 and 0603 MLCC components using the SAC305, SAC105 and SAC0307 solder through application of hot air reflow and vacuum soldering process, respectively, and comparative analysis on the void content in the solder joint, shear strength and microstructure was performed. The key findings can be outlined as follows.

1) Although the hot air reflow soldering process showed a stable void content in the joint at less than $5 \%$, the application of the vacuum soldering process markedly reduced the void content of the solder joint. However, there was no significant difference in void content with respect to the powder particle size of the solder in the same bonding process. However, it is expected that if temperature profile suitable for the finer powder can be applied, superior bonding properties can be achieved.

2) In terms of the bonding strength of the SAC305 solder joint under the same powder size condition, the result from the use of hot air reflow soldering showed greater bonding strength than that from the use of vacuum soldering. This indicates that the vacuum soldering process is effective in removing voids during the void joining process, and the reduction in the void content contributed to the enhancement of the bonding strength of the solder joint.

3) With the application of the hot air reflow soldering and vacuum soldering process, the bonding strength of the T4 SAC305 solder joint was slightly higher than that of the SAC105 and SAC0307 solder, but the overall initial bonding strength was similar between the result values. Therefore, within the Ag content of 0.3-3.0 $\mathrm{wt} \%$, the effect on the initial bonding strength of Sn$\mathrm{Ag}-\mathrm{Cu}$ solder is considered to be at the same level.

4) Various types of IMCs including $\mathrm{Cu}_{6} \mathrm{Sn}_{5}, \mathrm{Ag}_{3} \mathrm{Sn}$, $(\mathrm{Ni}, \mathrm{Cu}, \mathrm{Pd})_{3} \mathrm{Sn}_{4}(\mathrm{Cu}, \mathrm{Ni})_{6} \mathrm{Sn}_{5}, \mathrm{NiP}$, and $\mathrm{Ni}_{3} \mathrm{P}$ were formed on the interface between the ENEPIG finish substrate and SAC solder joint, and these IMCs are considered to contribute to the increase in the initial solder joint strength.

\section{Acknowledgments}

This research was conducted with the funding from the Material and Components Technology Development Project (Project number: 20011427) supported by the Ministry of Trade, Industry and Energy.

ORCID: Won Sik Hong: http://orcid.org/0000-0001-8398-177X ORCID: Mi-Song Kim: https://orcid.org/0000-0002-4717-9365 ORCID: Myeongin Kim: https://orcid.org/0000-0002-5151-1404

\section{References}

1. S. J. Kim, W. S. Hong, H. B. Nam, and N. H. Kang, Growth Behavior of Intermetallic Compounds in Various Solder Joints Induced by Electromigration, J. Weld. Join. 39(1) (2021) 89-102. https://doi.org/10.5781/JWJ.2021.39.1.11

2. G. T. Kim, G. H. Kang, and D. I. Kwon, Effect of Material Property Uncertainty on Warpage during Fan Out Wafer-Level Packaging Process, J. Microelectron. Packag. Soc. 26(1) (2019) 29-33. https://doi.org/10.6117/kmeps.2019.26.1.0029

3. C. I. Chen, C. Y. Ni, C. M. Chang, S. C. Wu, and D. S. Liu, Bondability Study of Chip-on-Film (COF) Inner Lead Bonding (ILB) Using Conventional Gang Bonder, IEEE Trans. Electro. Packag. Manuf. 31(4) (2008) 285-290.

4. W. S. Hong and C. M. Oh, PoF Based Accelerated Life Prediction with 3 Dimensional Packaging Technology Development, J. Korean Weld. Join. Soc. 27(3) (2009) 10-16.

5. W. S. Hong, S. B. Jung, and K. B. Kim, Analysis Method of Metallic Ion Migration, J. Korean Weld. Join. Soc. 23(2) (2005) 32-406.

6. Interactive User Guide, Multilayer Ceramic Capacitor, Samsum Electo-Mechanics Co, Ltd., Accessed on http://product.samsungsem.com/mlcc, $8^{\text {th }}$ July 2021.

7. Won Sik Hong and Chul Min Oh, Thermal Shock Reliability of Low Ag Composition Sn-0.3Ag- $0.7 \mathrm{Cu}$ and Near Eutectic Sn-3.0Ag-0.5Cu Pb-free Solder Joints, J. Korean Inst. Met. Mater. 47(12) (2009) 842-851.

8. W. S. Hong, W. S. Kim, B. S. Song, and K. B. Kim, Thermal Shock Cycles Optimization of Sn-3.0 Ag-0.5 $\mathrm{Cu}$ /OSP Solder Joint with Bonding Strength Variation for Electronic Components, Korean J. Mater. Res. 17(3) (2007) 152-159.

9. D. W. Suh, D. W. Kim, P. Liu, H. C. Kim, J. A. Weninger, C. M. Kumar, A. Prasad, B. W. Grimsley, and H. B. Tejada, Effects of Ag Content on Fracture Resistance of Sn-Ag-Cu Lead-Free Solders under High-Strain Rate Conditions, Mater. Sci. Eng. A. 460 (461) (2007) 595-603.

10. J. H. Back, B. S. Lee, S. H. Yoo, D. G. Han, S. B. Jung, and J. W. Yoon, Solderability of Thin ENEPIG Plating Layer for Fine Pitch Package application, $J$. Microelectron. Packag. Soc. 24(1) (2017) 83-90. https://doi.org/10.6117/kmeps.2017.24.1.083

11. J. Y. Park, M. S. Kim, C. M. Oh, S. H. Do, J. D. Seo, D. K. Kim, and W. S. Hong, Solder Joint Fatigue Life of Flexible Impact Sensor Module for Automotive Electronics, Korean J. Met. Mater. 55(4) (2017) 232-239. https://doi.org/10.3365/KJMM.2017.55.4.232

12. W. Liu, Y. Tian, C. Wang, and L. Sun, Formation of AuSnx IMCs in Sn3.5Ag0.75Cu Micro-Solder Joints Fabricated by Laser and Hot Air Reflow Processes, $J$. Mater. Sci. Mater. Electron. 24(1) (2012) 1-7. https://doi.org/10.1007/s10854-012-0715-8 


\title{
진공 및 열풍 리플로우 솔더링 접합공정에 따른 MLCC 접합특성
}

\section{MLCC Solder Joint Property with Vacuum and Hot Air Reflow Soldering Processes}

\author{
홍 원 식*·김 미 송*·김 명 인* \\ *한국전자기술연구원 융복합전자소재연구센터
}

\section{1. 서 론}

차세대 스마트 기기 및 네트워크 서버는 고속의 메모 리 속도가 요구되며, 메모리 속도를 증가시키기 위해서 는 반도체 소자의 범프 (Bump) 수가 증가되며, 이에 따라 범프 접합수를 기하급수적으로 증가시켜야 한다. 또한 범프 수 증가에 따라 Bump 간의 피치 (Pitch) 는 미세 피치화 됨에 따라 $100 \mu \mathrm{m}$ 이하의 초미세 Bump 피치를 갖는 패키징 기술이 요구된다 ${ }^{1-5)}$. 미세 피치 접합부 구현을 위해서는 미세피치 접합부 기술의 핵심 생산기술인 도금, 접합, 금형 등 기술이 복합적으 로 요구된다. 그러나 전자기기의 핵심 부품인 메모리 반도체 및 적층 세라믹 커패시터 (Multilayer ceramic capacitor, MLCC)의 국내 제조 기술은 각각 세계 선 두를 지키고 있으나, 반도체 핵심 배선공정 및 MLCC 제조에 사용되는 도금 소재, 공정장비 및 $\mathrm{MLCC}$ 전극 소재의 국산화율은 저조한 실정이다.

국산화 제품개발 및 상용 적용을 위해서는 다양한 소 재부품이 적용된 국산 반도체 패키징 부품 및 $\mathrm{MLCC}$ 와 같은 수동소자 내장형 모듈에 대한 제품 성능 확보 및 고내구 신뢰성이 확보되어야만 한다. 최근 모바일 제품의 사용 확대 및 다양한 어플리케이션 프로그램이 사용됨에 따라, 동시에 다양한 기능을 처리하기 위해 응용 프로세서 (Application processor, AP) 모듈의 사용이 급증하고 있다 ${ }^{4.5)}$. $\mathrm{AP}$ 모듈에는 $\mathrm{I} / \mathrm{O}$ 수가 매우 급증하고 있으며, $\mathrm{MLCC}$ 와 같은 수동소자가 임베디드 되어 있다. 반면 모바일 제품에 사용되는 $\mathrm{AP}$ 모듈의 크 기는 경박단소화 되고 있어, 여기에 내장되는 $\mathrm{MLCC}$ 와 같은 수동소자의 크기 또한 1005 크기에서 0603 또 는 0402 크기의 초소형 MLCC 부품이 실장 되고 있 다. 1,000 개 이상의 Bump 수를 갖는 $\mathrm{Si}$ 반도체 소자 는 열 압착 본딩 (Thermal compression bonding, TC bonding) 또는 플립칭 본딩 (Flip chip bonding)과 같이 온도와 압력을 가해 접합이 이루어진다. 반면 수동소자인 초소형 $\mathrm{MLCC}$ 부품의 경우, 일반적
인 솔더링 공정인 열풍 리플로우 솔더링 (Hot air reflow soldering) 공정을 통해 모듈화가 이루어지고 있 다. 그러나 Hot air reflow soldering 공정의 경우, 부품 소형화에 따라 MLCC 전극부의 면적도 감소되고 있어, MLCC 솔더 접합부의 보이드 (Void) 형성에 따 른 장기 접합신뢰성 저하의 원인이 되고 있다.

따라서 본 연구에서는 반도체 패키지 부품에 실장 되 는 초소형 1005와 0603 크기의 MLCC 부품과 Type 4 (T4)와 Type 7 (T7) 분말 입도를 갖는 $\mathrm{Sn}-\mathrm{Ag}-\mathrm{Cu}$ 계 3종 무연솔더 ( $\mathrm{Pb}$-free solder) 페이스트를 사용하 여 솔더 접합부 보이드 함유율 $3.0 \%$ 이내의 초소형 수동소자 부품의 솔더 접합공정을 최적화하였다. 솔더 접합부의 보이드 함유량 최소화를 위해 기존의 Hot air reflow soldering과 진공 솔더링 (Vacuum soldering) 공정을 적용하여 접합부의 보이드 결함 최소 화를 위한 공정 최적화 연구를 하였다.

\section{2. 실험 방법}

\section{1 반도체패키지용 기판 및 MLCC 부품}

실험에 사용된 플립칩 칩 스케일 패키지 (Flip-chip chip-scale-package, FCCSP) 기판은 Fig. 1과 같 이 열경화성 폴리이미드 (Polyimid) 수지의 일종인 비 스말레이미드 트리아진 (Bismaleimide Triazine, BT) 소재의 기판을 사용하였다. $\mathrm{BT}$ 재료는 비스말레이미드 (Bismaleimide) 종류와 트리아진 (Triazine) 수지를 주성분으로 하여 만들어진 절연체이다. BT 레진 (Resin) 은 플라스틱 소재로 내열성이 뛰어나 스마트폰, $\mathrm{PC}$ 등 에서 반도체(칩)와 반도체를 연결해 주는 회로기판에 주로 사용되고 있다. BT 기판의 두께는 $0.3 \mathrm{~mm}$ 였으 며, $\mathrm{BT}$ 기판의 패드 $(\mathrm{Pad})$ 표면은 무전해-니켈 무전 해-팔라듐 용융-금 (Elecroless-Nickel electrolessPaladium Immersion-Gold, ENEPIG) 도금의 표면 처리를 하였다. 표면처리 두께는 $\mathrm{Ni} 3-8 \mu \mathrm{m}, \mathrm{Pd} 0.05-$ $0.15 \mu \mathrm{m}, \mathrm{Au} 0.05-0.15 \mu \mathrm{m}$ 이였다. 

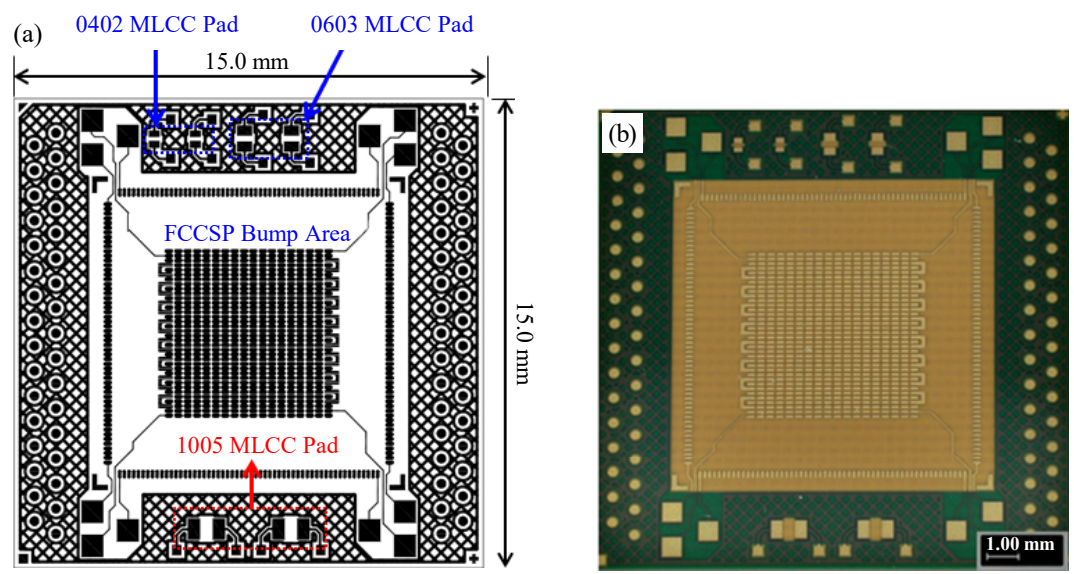

Fig. 1 Overview of flip-chip chip scale packaging, (a) schematic drawing and (b) optical micrograph of BT substrate

(a)

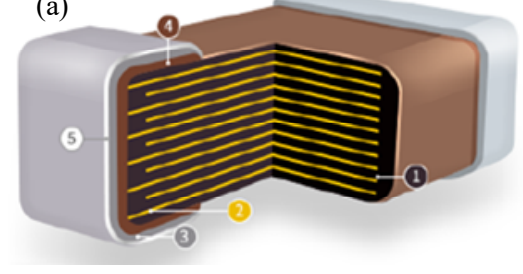

(1) Ceramic Body

(2) Electrode $\left(\mathrm{Ni} / \mathrm{Cu}^{*}\right)$

(3) Plating $(\mathrm{Ni})$

(4) Termination $(\mathrm{Cu}$ or $\mathrm{Cu}+$ Metal Epoxy)

(5) Plating (Sn) (b)

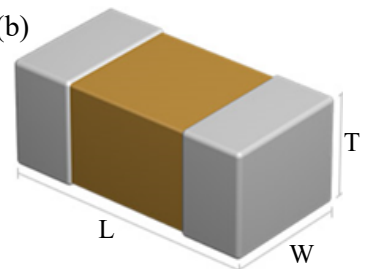

Fig. 2 Schematics of MLCC components ${ }^{6}$, (a) sectional view and (b) 3-dimensional image

Fig. 2는 BT 기판에 실장된 부품 사진으로, 삼성전기 에서 제조된 $1005 \mathrm{MLCC}(1.00(\mathrm{~L}) \times 0.50(\mathrm{~W}) \times 0.50(\mathrm{t})$ $\mathrm{mm}, 2.2-22 \mu \mathrm{F})$ 와 $0603 \mathrm{MLCC}(0.60(\mathrm{~L}) \times 0.30(\mathrm{~W}) \times$ $0.33(\mathrm{t}) \mathrm{mm}, 1-4 \mu \mathrm{F})$ 크기의 부품을 사용하였다 ${ }^{4)}$. MLCC 부품의 터미널 전극도금에는 $\mathrm{Ni}$ 하지도금과 $\mathrm{Sn}$ 도금이 적용되었다. 0603과 $1005 \mathrm{MLCC}$ 터미널 에 도금된 전극부 폭은 각각 $0.15 \pm 0.05 \mathrm{~mm}$ 와 $0.25 \pm$ $0.05 \mathrm{~mm}$ 이였다.

\section{2 무연 솔더 페이스트 및 프린팅 공정}

분말입도 차이에 따른 MLCC 접합특성 비교를 위 해, MLCC 실장에 사용된 무연솔더는 Table 1 과 같 이 4종의 페이스트를 사용하였다. 4종의 무연솔더는 $\mathrm{T} 4$ 와 $\mathrm{T} 7 \mathrm{Sn}-3.0 \mathrm{Ag}-0.5 \mathrm{Cu}$ (SAC305), $\mathrm{T} 4 \mathrm{Sn}-1$ $.0 \mathrm{Ag}-0.5 \mathrm{Cu} \quad$ (SAC105) 哭 $\mathrm{T} 4 \quad \mathrm{Sn}-0.3 \mathrm{Ag}-0.7 \mathrm{Cu}$ (SAC0307) 솔더 페이스트를 사용하였다. Fig. 3의
주사전자현미경 (Scanning electron microscopey, $\mathrm{SEM}$ ) 사진에서와 같이 Type 4와 Type 7 솔더 페이 스트의 분말입도의 차이를 나타낸다. Type 7 의 분말입 도가 매우 미분이라 미세피치 솔더 페이스트 인쇄 (Printing)에 보다 적합한 것으로 판단된다.

솔더 페이스트 인쇄는 $100 \mu \mathrm{m}$ 두께 SUS 재질의 메 탈 마스크 (Metal mask)를 사용하여 개구율 100\% 로 제작하였다. 인쇄 후에는 30 배율의 광학현미경을 사용하여 솔더 페이스트의 인쇄 상태를 검사하였다.

\section{3 열풍 및 진공 리플로우 솔더링}

$\mathrm{MLCC}$ 솔더 접합을 위한 공정은 Fig. 4와 같이 $\mathrm{Hot}$ air reflow soldering (Heller Co. Ltd., 1809UL, USA) 과 Vacuum soldering (Unitemp Co. Ltd., RSS210-S, Germany) 공정을 적용하여 기판과 MLCC 접합부의 보이드 결함 최소화 조건으로 솔더링 공정 최 적화를 진행하였다. Hot air reflow soldering 공정

Table 1 Chemical composition, type and powder size of $\mathrm{Pb}$-free solder pastes

\begin{tabular}{|c|c|c|c|}
\hline Solder alloy composition & Solder paste type & Powder size $(\mu \mathrm{m})$ & Manufacturer \\
\hline \multirow{2}{*}{ Sn-3.0Ag-0.5Cu (SAC305) } & $\mathrm{T} 4$ & $20-38$ & \multirow{2}{*}{$\begin{array}{l}\text { MK Electron Co., Ltd. } \\
\text { (Korea) }\end{array}$} \\
\hline & $\mathrm{T} 7$ & $5-15$ & \\
\hline $\mathrm{Sn}-1.0 \mathrm{Ag}-0.5 \mathrm{Cu} \quad(\mathrm{SAC} 105)$ & \multirow{2}{*}{$\mathrm{T} 4$} & \multirow{2}{*}{$20-38$} & \multirow{2}{*}{$\begin{array}{l}\text { Ecojoin Co., Ltd. } \\
\text { (Korea) }\end{array}$} \\
\hline Sn-0.3Ag-0.7Cu (SAC0307) & & & \\
\hline
\end{tabular}




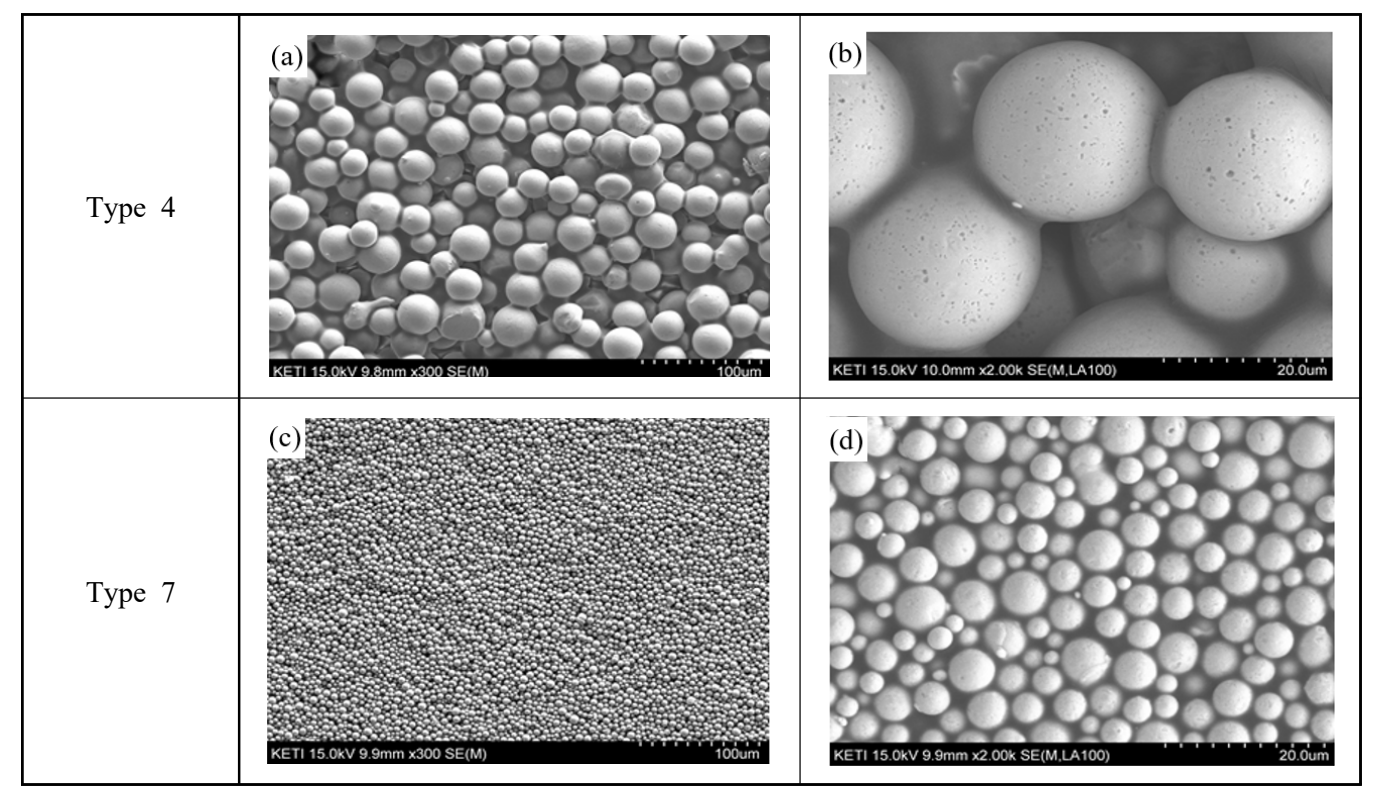

Fig. 3 SEM micrographs of (a,b) Type 4 and (c,d) Type 7 solder paste of Sn-3.0Ag-0.5Cu solder alloy
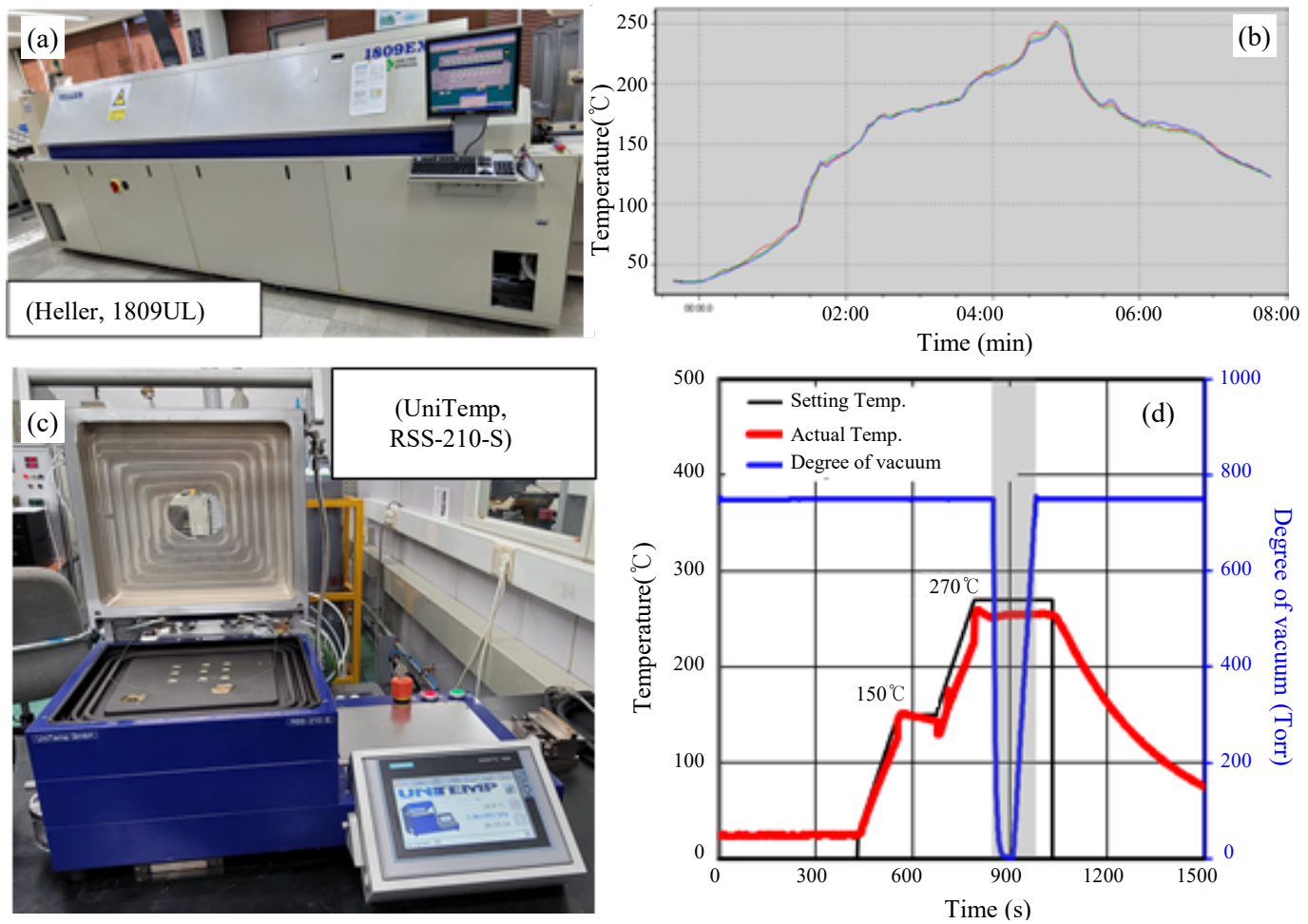

Fig. 4 Photographs of (a) hot air reflow machine and (b) temperature profile, and (c) vacuum soldering machine and (d) temperature and vacuum profile

은 예열온도 $150-160{ }^{\circ} \mathrm{C}$, 최고온도 $245-250{ }^{\circ} \mathrm{C}$ 에서 30s로 총 $8 \mathrm{~min}$ 동안 Hot air reflow soldering 공정 을 통해 접합하였다. Vacuum soldering 접합은 예열온 도 $150^{\circ} \mathrm{C}, 120 \mathrm{~s}$, 본 열 구간 최고온도 $255^{\circ} \mathrm{C}, 180 \mathrm{~s}$, 진공도 $5 \mathrm{hPa}$ (3.75 torr) 조건으로 총 $17.5 \mathrm{~min}$ 동안 접합공정을 진행하였다.
2.4 솔더 접합부 보이드 함유율 측정 및 접합 강도 시험

솔더 접합부의 보이드 함유율 측정은 솔더의 접합된 면적 내에 존재하는 보이드의 면적으로 계산하였으며, 보이드 측정은 X-선 비파괴분석 (X-Ray non-destruc- 
tive microscope) 장비 (Resolution, X-Tek Co. Ltd., $\mathrm{UK})$ 를 사용하였다. $\mathrm{MLCC}$ 칩 부품의 솔더 접합강도 측정은 Dage 4000 (Nordson Co., Ltd., USA) 장 비를 사용 하였고, $\mathrm{MLCC}$ 솔더 접합부에 대해 전단강 도 측정시험 (Shear strength test)을 진행하였다. 전단강도 시험은 시험속도 $167 \mu \mathrm{m} / \mathrm{sec}$, 시험치구 높이 는 기판으로부터 $50 \mu \mathrm{m}$ height 조건으로 측정 하였으 며, 솔더 페이스트의 종류와 Type에 따른 접합강도를 비교분석 하였다.

\section{3. 실험 결과}

\subsection{MLCC 솔더 접합부 보이드 함유율}

$\mathrm{MLCC}$ 솔더 접합을 위해 Fig. 5에서와 같이 기판 패드면 위에 솔더 페이스틀 인쇄한 후 광학현미경을 이 용하여 인쇄상태를 관찰하였다. 기판 패드면 위에 솔더 페이스트가 인쇄된 후 슬럼프 (Slump)를 잘 형성하며 유지되고 있었다. 인쇄된 솔더 페이스트 위에 $\mathrm{MLCC}$ 칩을 마운팅 (Mounting) 한 후 Reflow soldering과 Vacuum soldering 공정을 이용하여 접합공정을 진행 하였다. 솔더링 후 1005 와 $0603 \mathrm{MLCC}$ 접합부 관찰
결과 Fig. 6과 Fig. 7에서 보는 것과 같이 솔더 필렛 (Fillet)을 양호한 접합 상태를 확인할 수 있었다. Fig. 8은 솔더 종류와 솔더링 공정에 따른 접합부에서 의 보이드 함유량을 정리 비교하였다. Hot air reflow soldering 공정으로 접합된 $1005 \mathrm{MLCC}$ 접합부의 보 이드 햠유량은 대략 1.6-4.3\% 수준 이였으며, 0603 칩은 대략 1.1-3.7\% 정도였다. 반면, Vacuum soldering 공정으로 접합된 $1005 \mathrm{MLCC}$ 접합부 보이드 함유량은 0.1-0.7\% 이였고, 0603 칩의 보이드는 0.5$1.5 \%$ 수준으로 나타났다. Hot air reflow soldering 공정에서도 $5 \%$ 이하의 안정적인 접합부 보이드 함유율을 나타내고 있었지만, Vacuum soldering의 경우 접합부의 보이드 함유량이 현저히 감소 된 것을 알 수 있었다. Vacuum soldering 공정은 Fig. 4(d) 와 같이 온도 프로파일 중 본열 온도구간에서 진공 상 태를 유지함으로써 용융된 솔더 내부의 보이드 유동성 이 증가하여 접합부 보이드가 감소된 것으로 판단된다. 일반적으로 부품의 크기나 접합부 면적이 작아질수록 용융솔더 내부의 보이드는 접합되는 기판의 패드나 솔 더와 접촉되는 면과의 표면장력이 더 크게 작용하게 됨 으로써 보이드 함유량이 증가하는 경향이 있다. 이러한 이류로 일반 리플로우 공정에서 완전한 보이드 제거가

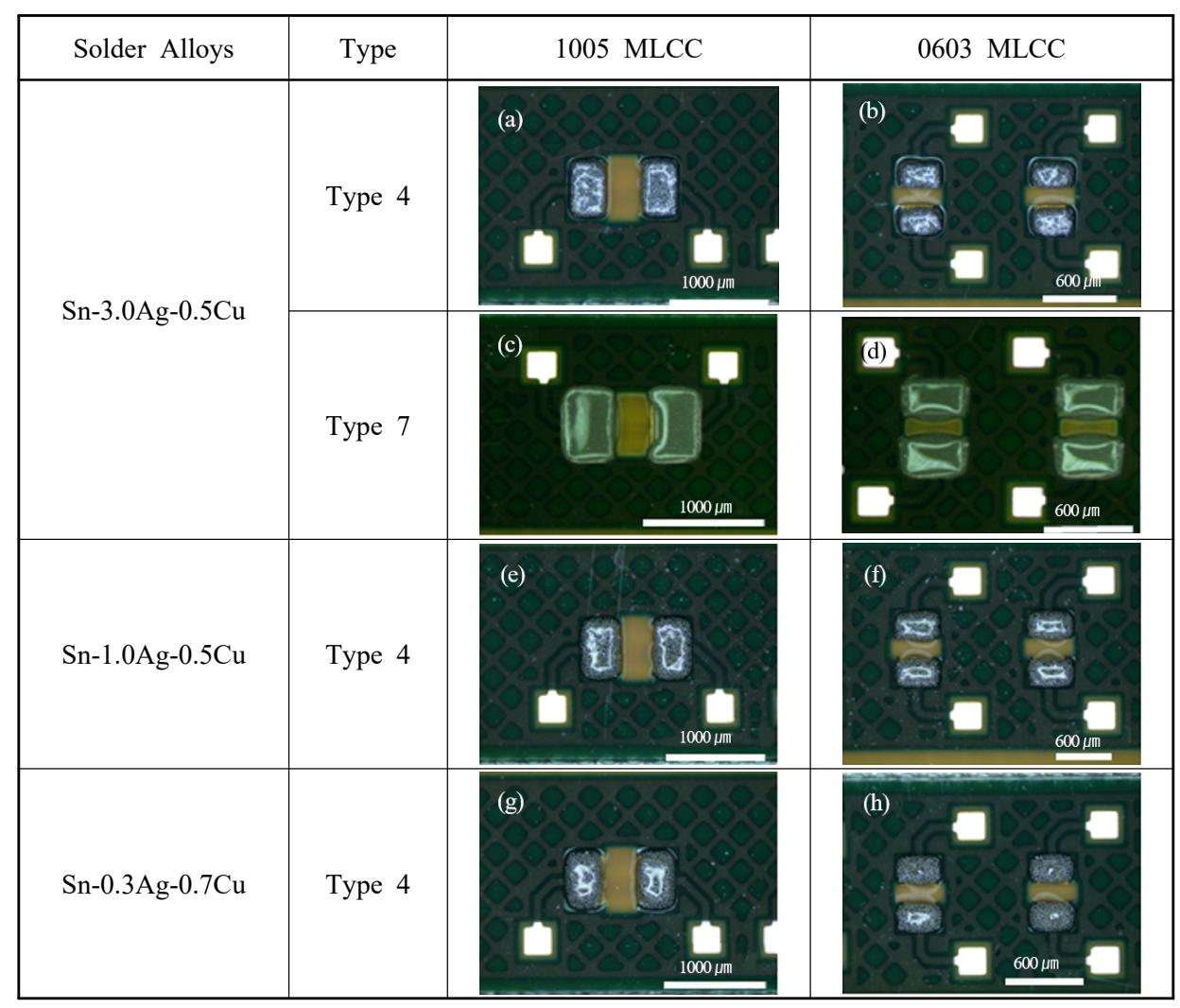

Fig. 5 Optical micrographs after printing process with various solder alloys and types, (a-d) Sn-3.0Ag-0.5Cu, (e,f) $\mathrm{Sn}-1.0 \mathrm{Ag}-0.5 \mathrm{Cu}$ and $(\mathrm{g}-\mathrm{h}) \mathrm{Sn}-0.3 \mathrm{Ag}-0.7 \mathrm{Cu}$ solder pastes 


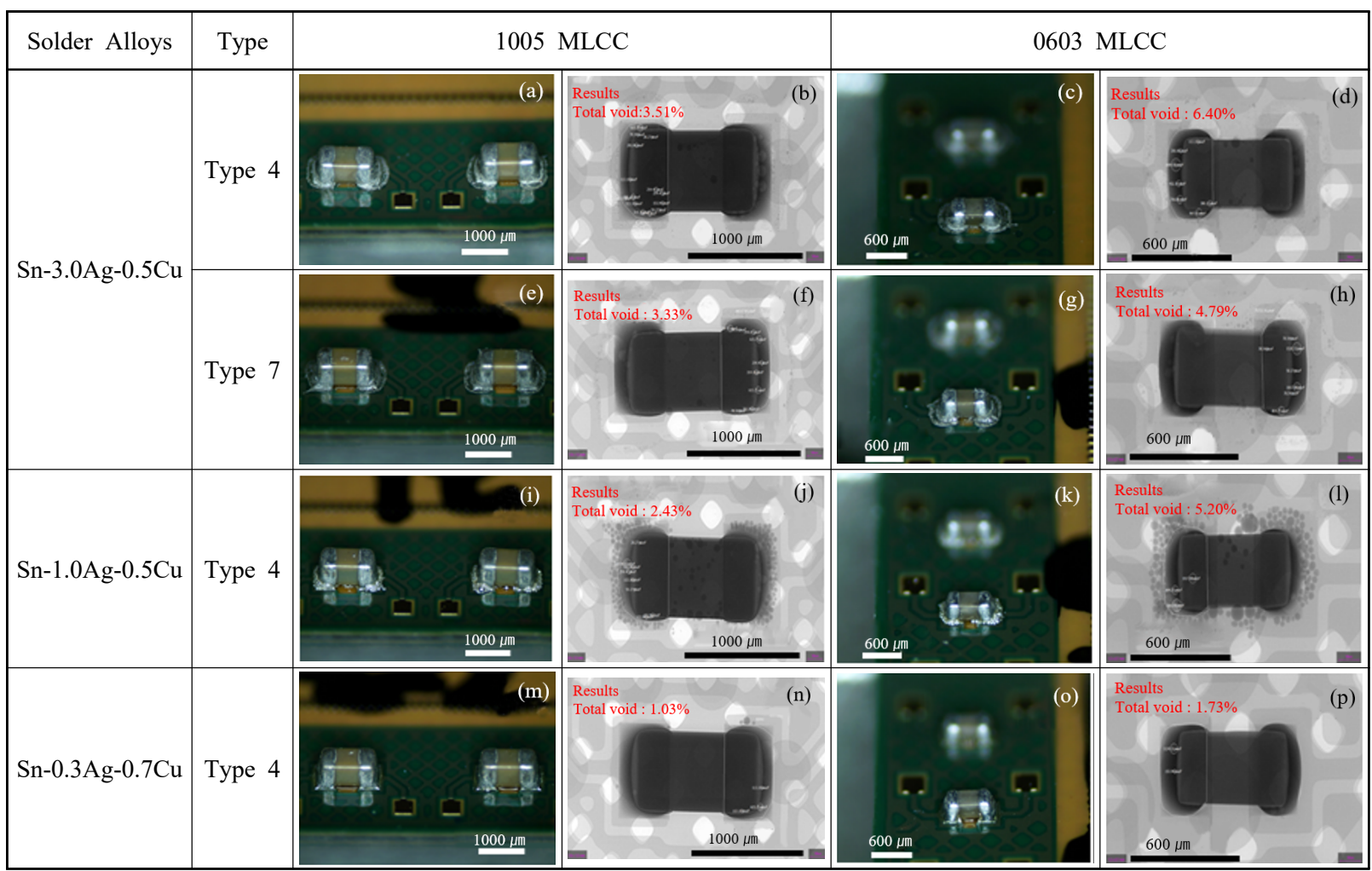

Fig. 6 Optical micrographs and X-ray non-destructive void content of 1005 and 0603 MLCC solder joints with (a-h) Sn-3.0Ag-0.5Cu, (i-1) Sn-1.0Ag-0.5Cu and (m-p) Sn-0.3Ag-0.7Cu solder alloys using by hot air reflow soldering process

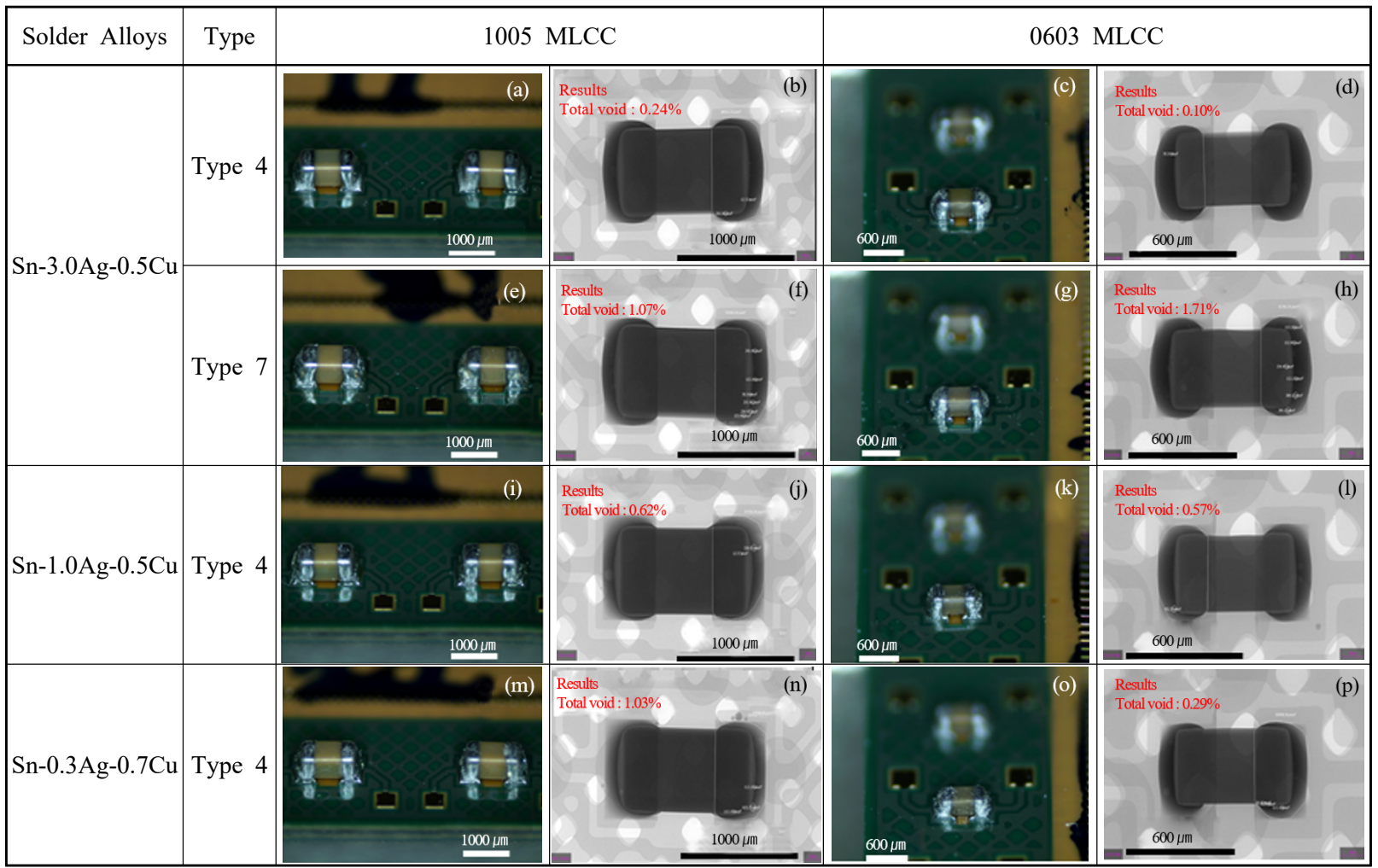

Fig. 7 Optical micrographs and X-ray non-destructive void content of 1005 and 0603 MLCC solder joints with (a-h) $\mathrm{Sn}-3.0 \mathrm{Ag}-0.5 \mathrm{Cu}$, (i-1) Sn-1.0Ag-0.5Cu and (m-p) Sn-0.3Ag-0.7Cu solder alloys using by vacuum soldering process 


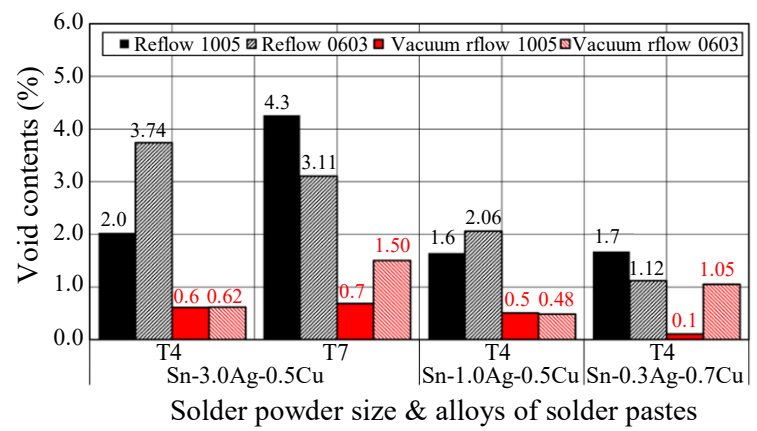

Fig. 8 Void content comparison between hot air reflow and vacuum soldering process with various alloy compositions and powder size of the solder pastes

되지 않는 것을 Vacuum soldering 공정을 이용하여 효과적으로 제거할 수 있는 것을 알 수 있었다. 또한 동일한 $\mathrm{SAC} 305$ 솔더의 경우, $\mathrm{T} 4$ 와 T7 페이스트에서 거의 유사한 보이드 함유량을 나타냈지만, 1005 칩의 경우 $\mathrm{T} 7$ 이 다소 많은 보이드 함유량을 나타내었다. 이 것은 $\mathrm{T} 4$ 와 $\mathrm{T} 7$ 솔더 페이스트에 동일한 온도 프로파일 을 적용하여 나타난 결과로 사료되며, 솔더의 분말입도 가 작아질수록 기존의 $\mathrm{T} 4$ 와 다른 온도 조건을 적용하 는 것이 적합한 것으로 판단된다. T4 분말입도를 갖는 $\mathrm{SAC} 105$ 와 $\mathrm{SAC} 0307$ 솔더 모두에서 보이드 함유량은 $2 \%$ 이하로 유사한 수준을 나타내었다.

\subsection{MLCC 솔더 접합부 접합강도}

Fig. 9는 일반 Hot air reflow soldering과 Vacuum soldering 공정으로 접합된 각각 4개의 동일한 1005 및 $0603 \mathrm{MLCC}$ 솔더 접합부의 접합강도 평균값 이 다. 동일한 T4 SAC305 솔더와 $1005 \mathrm{MLCC}$ 를 사용한 Hot air reflow soldering와 Vacuum soldering 공 정의 접합강도는 각각 $1.06 \pm 0.08 \mathrm{kgf}$ 과 $1.73 \pm 0.11$ $\mathrm{kgf}$ 이였고, $0603 \mathrm{MLCC}$ 는 각각 $0.64 \pm 0.04 \mathrm{kgf}$ 와 $0.70 \pm 0.02 \mathrm{kgf}$ 이였다. T7 SAC305 솔더의 경우 1005 와 $0603 \mathrm{MLCC}$ 솔더 접합강도는 각각 $1.43 \pm$

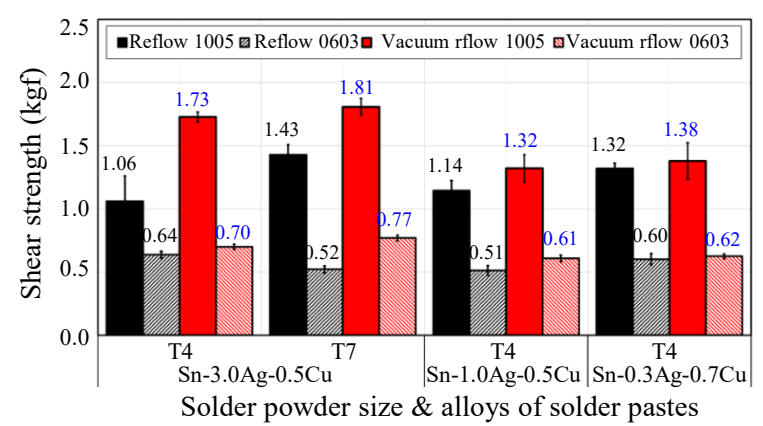

Fig. 9 Shear strength comparison between hot air reflow and vacuum soldering process with various alloy compositions and powder size of the solder pastes

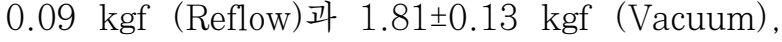
그리고 $0.52 \pm 0.08 \mathrm{kgf}$ (Reflow)와 $0.77 \pm 0.03 \mathrm{kgf}$ (Vacuum) 으로 측정되었다. 솔더 접합공정과 무관하게 측정된 모든 부품의 표준편차 범위는 대략 $\pm 0.1 \mathrm{kgf}$ 내외로 나타난 것으로 보아, 접합공정의 차이에 의한 접합강도 편차가 발생된 것을 알 수 있었고, Vacuum soldering이 Hot air reflow soldering 공정보다 다 소 높은 접합강도를 나타내었다.

동일한 SAC305 솔더에서 $\mathrm{T} 4$ 와 $\mathrm{T} 7$ 분말입도의 차 이에 따른 접합강도를 비교하면, Hot air reflow soldering와 Vacuum soldering 은 각각 1.06 과 $1.43 \mathrm{kgf}$ 이였으며, Vacuum soldering 공정에서는 각각 1.73 과 $1.81 \mathrm{kgf}$ 로 측정되었다. 다만 동일한 $\mathrm{T} 4$ 분말입도 를 갖는 경우 접합공정이 동일하면 $\mathrm{Ag}$ 함량에 무관하 게 SAC305 솔더의 초기 접합강도는 유사한 수준으로 나타났다. 이러한 결과로 볼 때, 동일한 솔더 조성인 경우, Hot air reflow soldering 보다 Vacuum soldering 한 것이 접합강도가 더 높게 나타났다. 또한 동일 $\mathrm{SAC} 305$ 조성에서 분말일도가 미분인 $\mathrm{T} 7$ 이 $\mathrm{T} 4$ 보다 다소 높은 접합강도를 나타내었다.

또한 T4 SAC305, T4 SAC105와 T4 SAC0307 의 접합강도를 비교해 보면, 1005 칩은 1.06-1.32 kgf (Reflow)와 1.32-1.73 kgf (Vacuum) 였고, 0603 칩은 0.51-0.64 kgf (Reflow)와 0.61-0.77 kgf (Vacuum)로 나타났다. 이것은 솔더의 합금조성에서 $\mathrm{Ag}$ 의 함량이 서로 다른 솔더 이였으나, 동일한 공정과 동 일한 크기의 칩 부품의 접합강도는 $\mathrm{SAC} 305, \mathrm{SAC} 105$ 그리고 SAC0307 솔더 모두 동등한 수준으로 나타났 다. 이것은 $\mathrm{Sn}-\mathrm{Ag}-\mathrm{Cu}$ 공정조성 합금계에서 $\mathrm{Ag}$ 의 함 량이 0.3-3.0 wt\% 범위 내에서는 솔더 접합부의 초기 접합강도는 동등한 수준인 것으로 나타났다. $\mathrm{Hong}^{7-9)}$ 의 선행 연구결과를 보면, 열충격 2000 Cycles 이후 $\mathrm{SAC} 305$ 와 $\mathrm{SAC} 0307$ 솔더 모재 내 존재하는 $\mathrm{Ag}_{3} \mathrm{Sn}$ 함유량을 비교해 보면, $\mathrm{SAC} 0307$ 솔더가 작은 것을 알 수 있었다. 솔더 모재에 존재하는 $\mathrm{Ag}$ 함유량이 적 어질수록 primary-Sn의 생성 양이 증가되고, 이에 따 라 $\mathrm{Ag}_{3} \mathrm{Sn}$ 을 형성하기 위한 $\mathrm{Sn}$ 의 양은 적어지 게 됨으 로 $\mathrm{SAC0307}$ 솔더에서 $\mathrm{Ag}_{3} \mathrm{Sn}$ 상 분율이 $\mathrm{SAC} 305$ 보 다 감소된다고 보고하고 있다. 결국 미세 분산된 $\mathrm{Ag}_{3} \mathrm{Sn}$ 은 솔더 접합부의 초기 접합강도 증가에 기여하 지만, 시효온도가 증가되고, 고온에 장시간 동안 노출 되는 경우 $\mathrm{Ag}_{3} \mathrm{Sn}$ 의 성장과 조대화에 의해 솔더 접합 부의 접합강도가 감소된다고 보고 하였다 ${ }^{7-9)}$.

그러나 본 연구에서 사용된 솔더링 공정에서는 Hot air reflow 보다 Vacuum soldering 공정에서 다소 
높은 접합강도를 나타내고 있어, Vacuum soldering 공정이 보이드 함유량을 감소시킴으로써 솔더 접합부의 접합강도 향상에 기여함을 알 수 있었다. 본 실험결과 는 초기 접합강도 차이를 비교한 것으로써, 장기적인 솔더 접합부 신뢰성 비교를 위해서는 열충격시험을 통 한 합금조성과 분말입도의 차이를 비교해야 할 것으로 판단된다.

\section{3 솔더 접합부 계면분석}

1005와 0603 MLCC T7 SAC305 Hot air reflow 솔더 접합부에 대한 단면분석 사진은 각각 Fig. 10와 Fig. 11에 나타내었다. 솔더 접합부의 보이드 함 유량은 매우 적었으며, 접합부 Fillet도 양호하게 형성 된 것을 관찰할 수 있었다. 칩과 기판의 솔더 접합부 계면에는 $(\mathrm{Cu}, \mathrm{Ni})_{6} \mathrm{Sn}_{5}$, 금속간화합물 (Intermetallic compound, IMC)가 형성된 것을 알 수 있었다. 일반 적으로 무전해 니켈-침지 금 (Electroless Nickel Immersion Gold, ENIG) 또는 ENEPIG 표면처리된 SAC305 솔더 접합계면세서는 $(\mathrm{Cu}, \mathrm{Ni})_{6} \mathrm{Sn}_{5}, \quad(\mathrm{Ni}, \mathrm{Cu})_{3} \mathrm{nSn}_{4}$,
$\mathrm{IMC}$ 가 형성된다. 또한 $\mathrm{Ni}$ 도금층과 솔더의 접합계면 에는 NiP, Ni3P, Ni3P4 등의 Ni-P IMC가 형성되 며, 솔더 접합부 모재 부분에서는 $\mathrm{Ag}_{3} \mathrm{Sn}, \mathrm{Cu}_{6} \mathrm{Sn}_{5}$ 가 형 성된다고 알려져 있다 $7,8,10-11)$. 본 연구에서도 Fig. 9(b-c) 에서와 같이 SAC305 솔더와 ENEPIG 접합부 계면 에서는 솔더링된 이후 초기 접합계면에서 $(\mathrm{Cu}, \mathrm{Ni}, \mathrm{Pd})_{6} \mathrm{Sn}_{5}$ 와 $(\mathrm{Ni}, \mathrm{Cu}, \mathrm{Pd})_{3} \mathrm{nSn} \mathrm{I}_{4} \mathrm{IMC}$ 가 형성된 것이 관찰되었 다. Fig. 12은 $0603 \mathrm{MLCC}$ 칩 부품의 SAC105 솔더 접합부 단면분석 $\mathrm{SEM}$ 사진이다. 솔더 접합부 Fillet의 모재 부분에서는 $\mathrm{SAC}$ 조성에서 관찰되는 전형적인 $\mathrm{Cu}_{6} \mathrm{Sn}_{5}$ 와 $\mathrm{Ag}_{3} \mathrm{Sn} \mathrm{IMC}$ 가 관찰되었고, MLCC-ENEPIIG 기판 접합부 계면에서는 $(\mathrm{Ni}, \mathrm{Cu}, \mathrm{Pd})_{3} \mathrm{nSn} \mathrm{Sn}_{4} \mathrm{IMC}$ 가 형 성된 것이 관찰되었다. 또한 $\mathrm{ENIG}$ 표면처리의 경우, 모재에서 $\mathrm{Au}-\mathrm{Sn}$ 화합물이 검출되기도 한다 ${ }^{12)} . \mathrm{Au}^{-} \mathrm{Sn}$ $\mathrm{IMC}$ 로는 $\mathrm{AuSn}, \mathrm{Au}_{2} \mathrm{Sn}, \mathrm{AuSn}_{2}, \mathrm{AuSn}_{4}$ 등 다양한 종류의 $\mathrm{IMC}$ 가 존재하며, Fig. 9(b)의 접합부에서도 미량의 침상 (Needle)의 $\mathrm{Au}_{2} \mathrm{Sn} \mathrm{IMC}$ 가 검출되었다.

Fig. 13는 0603 MLCC-기판의 SAC105 Hot air reflow 솔더 접합부에 대한 단면 SEM 사진이다.
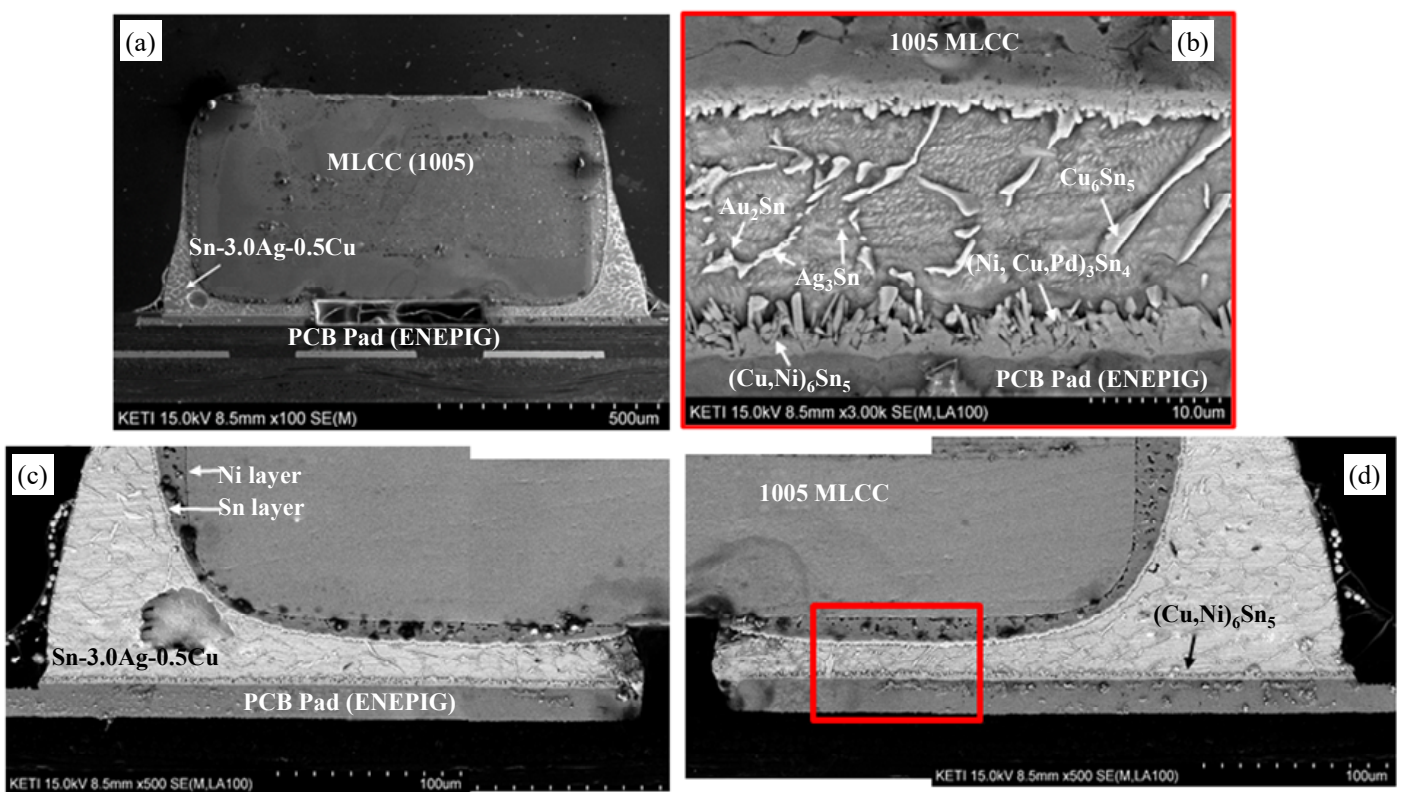

Fig. 10 SEM micrographs of 1005 MLCC solder joint with Type 7 Sn-3.0Ag-0.5Cu solder after hot air reflow soldering

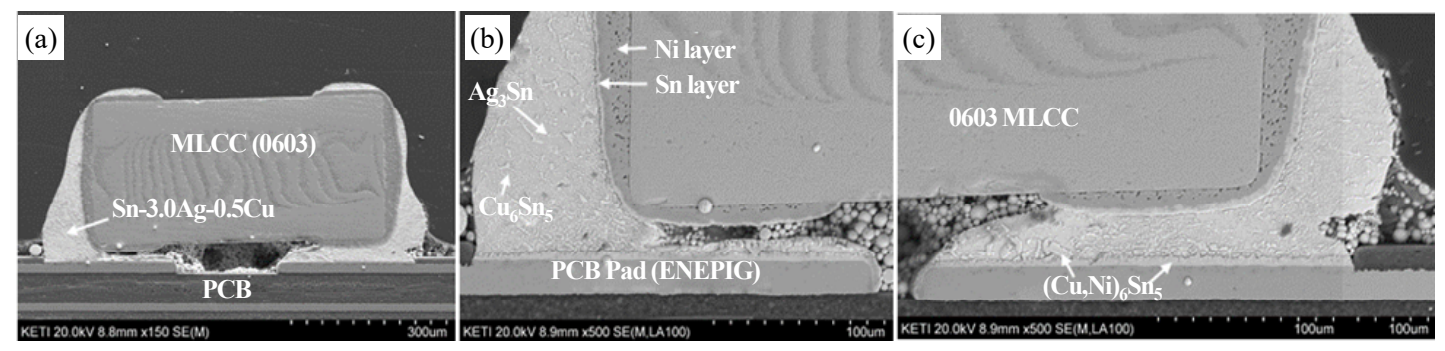

Fig. 11 SEM micrographs of 0603 MLCC solder joint with Type 7 Sn-3.0Ag-0.5Cu solder after hot air reflow sol 


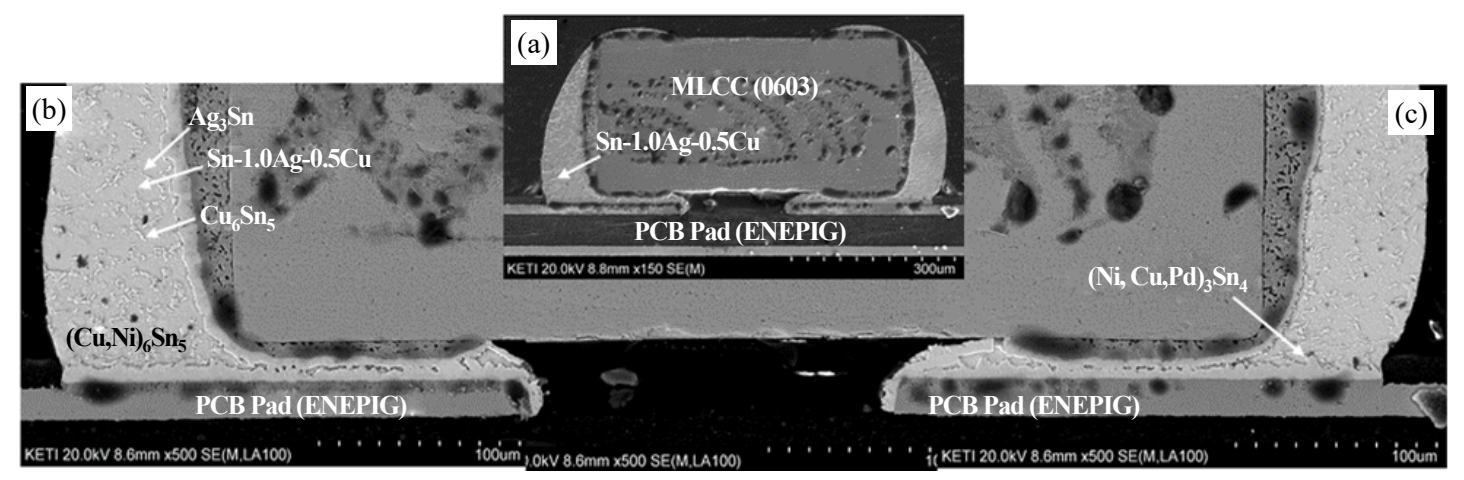

Fig. 12 SEM micrographs of 0603 MLCC solder joint with Type 4 Sn-1.0Ag-0.5Cu solder after vacuum soldering
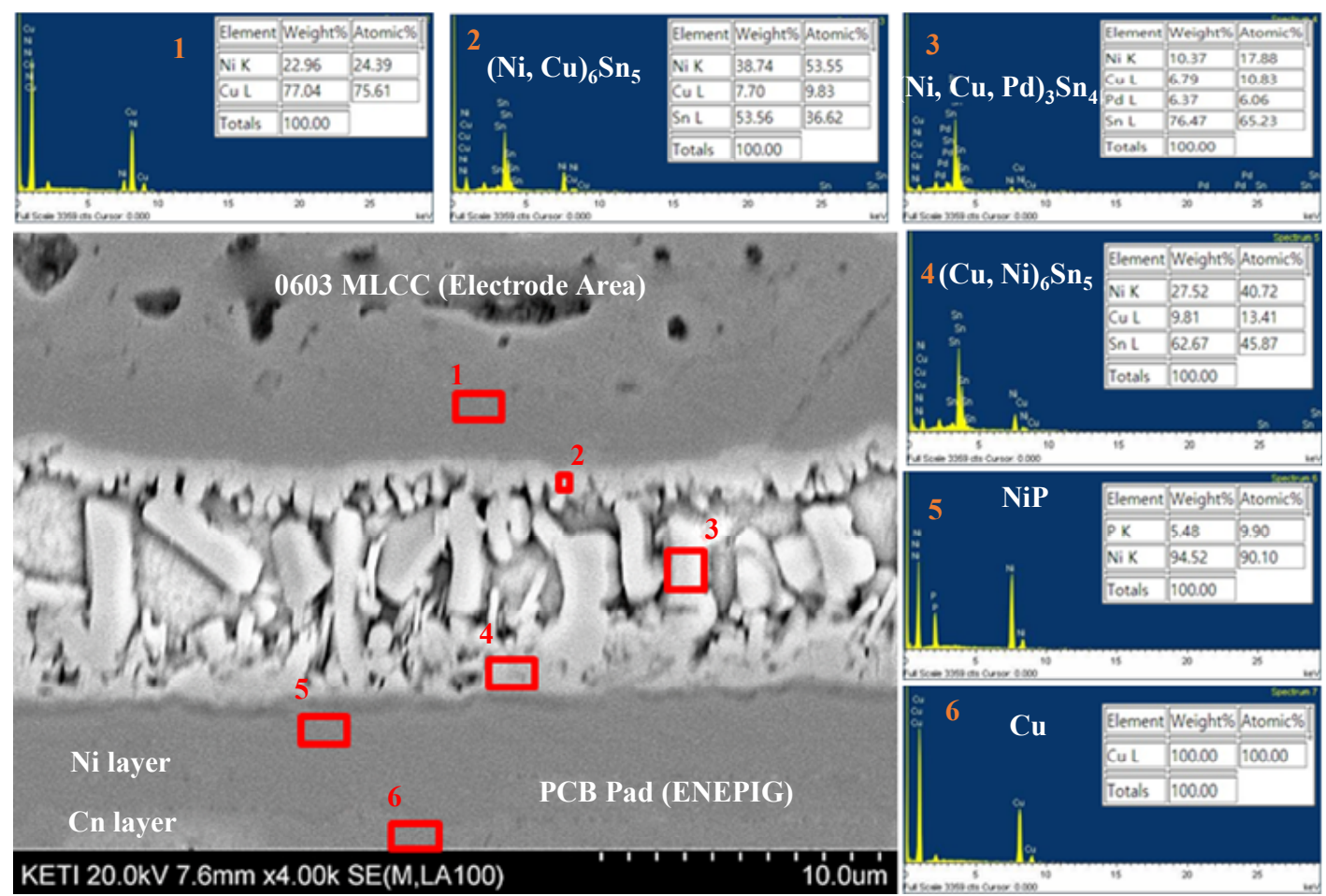

Fig. 13 SEM micrograph and EDS analysis results of 0603 MLCC solder joint between BT substrate and MLCC with Type $4 \mathrm{Sn}-1.0 \mathrm{Ag}-0.5 \mathrm{Cu}$ solder after hot air reflow soldering

$\mathrm{MLCC}$ 전극부 솔더 접합계면에서는 불규칙한 침상 형 태의 $\left(\mathrm{Cu}, \mathrm{Ni}_{6} \mathrm{Sn}_{5}\right.$ 가 형성되었고, 접합부 솔더 층에서는 $(\mathrm{Ni}, \mathrm{Cu}, \mathrm{Pd})_{3} \mathrm{Sn}_{4}, \mathrm{Ag}_{3} \mathrm{Sn}, \mathrm{Cu}_{6} \mathrm{Sn}_{5} \mathrm{IMC}$ 가 형성되었 다. 솔더-BT 기판의 접합계면에는 $\mathrm{NiP},\left(\mathrm{Cu}, \mathrm{Ni}_{6}\right)_{6} \mathrm{Sn}_{5}$ $\mathrm{IMC}$ 가 관찰되었다. Fig. 14 은 솔더-BT 기판의 접합 계면이 주로 형성된 부분의 $\mathrm{SEM}$ 과 $\mathrm{EDS}$ 분석 결과이 다. 솔더 모재 부분에는 $\mathrm{Cu}_{6} \mathrm{Sn}_{5}$ 와 $\mathrm{Ag}_{3} \mathrm{Sn}$ 및 침상의 $(\mathrm{Ni}, \mathrm{Cu}, \mathrm{Pd})_{3} \mathrm{Sn}_{4} \mathrm{IMC}$ 가 형성되었고, 기판의 솔더 접합 계면에서는 $(\mathrm{Ni}, \mathrm{Cu}, \mathrm{Pd})_{3} \mathrm{Sn}_{4},\left(\mathrm{Cu}, \mathrm{Ni}_{6}\right)_{6} \mathrm{Sn}_{5}, \mathrm{NiP}, \mathrm{Ni}_{3} \mathrm{P}$ $\mathrm{IMC}$ 가 형성된 것을 알 수 있었다. 이러한 $\mathrm{ENEPIG}$ 표면처리 기판과 $\mathrm{SAC}$ 조성의 솔더 접합계면에는 다야 한 $\mathrm{IMC}$ 가 형성되면, 시간의 경과에 따라 나타나는 IMC
의 성장거동이 솔더 접합부의 장기적인 신뢰성에 영향 을 미치는 것으로 알려져 있다 $7,8,10,11$. 본 연구에 나타 난 다양한 $\mathrm{IMC}$ 는 초기 접합강도 향상에 기여하지만, 패드 표면처리 층에 따라 생성된 IMC 종류는 변화가 있고 솔더의 type과 $\mathrm{Ag}$ 의 조성에 따라서는 거의 동일 한 $\mathrm{IMC}$ 가 생성되었다. 그러나 장기적으로는 접합부 열화를 유발하는 인자로도 작용하는 것으로 판단되므로 추가적인 연구가 필요할 것으로 판단된다.

\section{4. 결 론}

본 연구에서는 1005와 0603 MLCC 부품을 SAC305, 

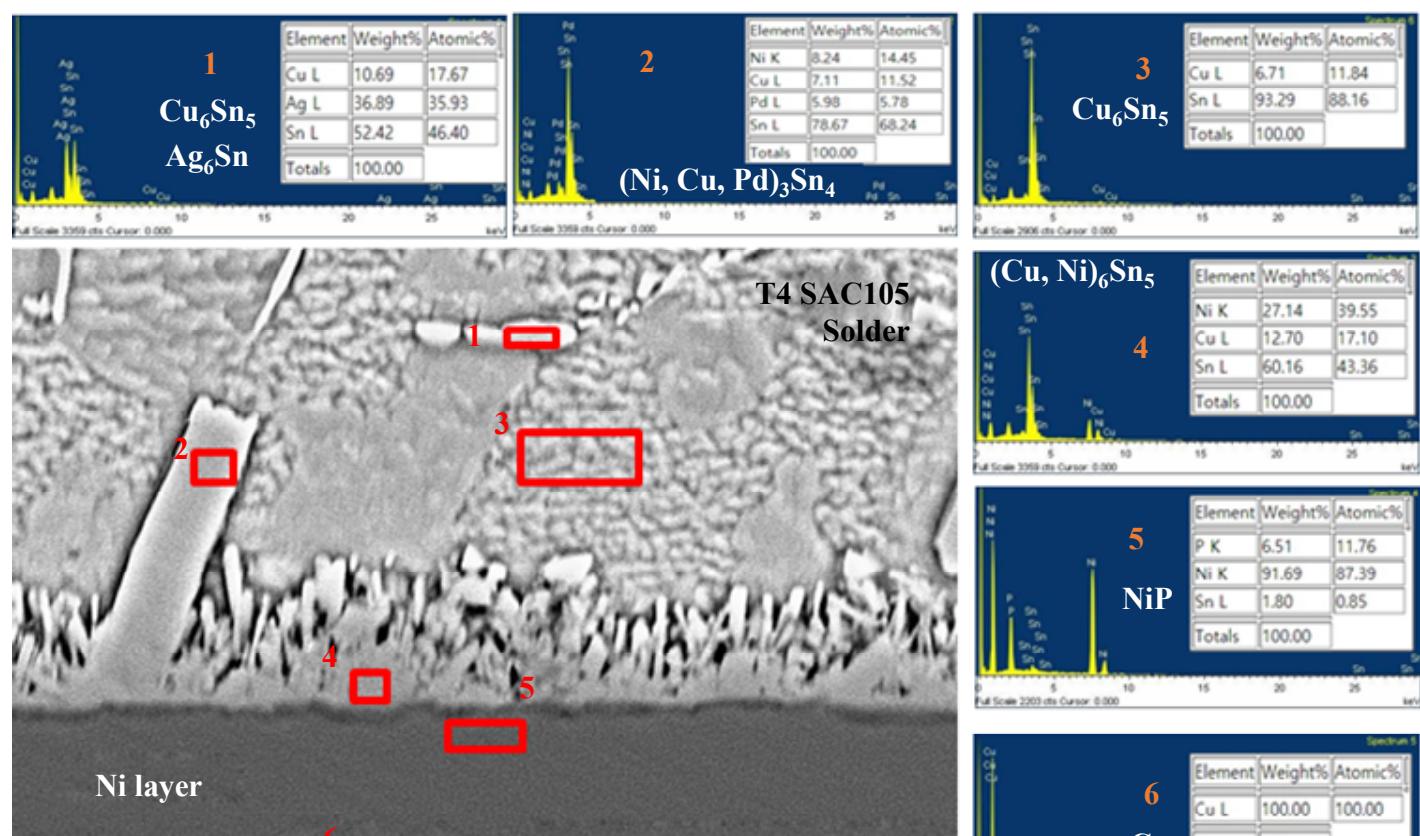

Cu layer

PCB Pad (ENEPIG)

KETI 20.0kV 7.6mm x4.00k SE(M,LA100)

'10.0́um

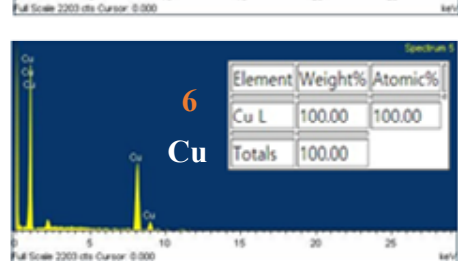

Fig. 14 SEM micrograph and EDS analysis results of 0603 MLCC solder joint between BT substrate and solder interface with Type $4 \mathrm{Sn}-1.0 \mathrm{Ag}-0.5 \mathrm{Cu}$ solder after hot air reflow soldering

$\mathrm{SAC} 105$ 및 SAC0307 솔더를 사용하여 Hot air reflow와 Vacuum soldering 공정으로 접합한 후, 접합 부 보이드 함유율 및 접합강도와 미세조직 분석을 통해 접합공정의 차이를 비교분석하였으며, 그 결과는 다음 과 같다.

1) Hot air reflow soldering 공정에서도 $5 \%$ 이하 의 안정적인 접합부 보이드 함유율을 나타내고 있었지 만, Vacuum soldering의 경우 솔더 접합부의 보이드 함유량이 현저히 감소되는 것을 알 수 있었다. 그러나 동일 접합공정에서 솔더의 분말 입도에 따른 보이드 함 유량의 차이는 크게 나타나지 않았다. 하지만 미세분말 에 적합한 온도 프로파일을 적용한다면 보다 우수한 접 합특성을 얻을 수 있을 것으로 판단된다.

2) 동일한 분말입도를 갖는 $\mathrm{SAC} 305$ 솔더 접합부의 접합강도는 Hot air reflow soldering 보다 Vacuum soldering 된 접합부 강도가 큰 것으로 나타났다. 이 것은 Vacuum soldering 공정이 보이드 접합공정 중 보이드 제거에 효과적이며, 보이드 함유량을 감소시킴 으로써 솔더 접합부의 접합강도 향상에 기여함을 알 수 있었다.

3) 동일한 Hot air reflow soldering 및 Vacuum soldering 접합공정을 적용한 경우, $\mathrm{T} 4 \mathrm{SAC} 305$ 솔 더 접합강도가 $\mathrm{SAC} 105$ 와 $\mathrm{SAC} 0307$ 솔더 접합강도
보다 다소 높기는 하지만, 전체적인 초기 접합강도는 유 사한 수준으로 나타났다. 따라서 $\mathrm{Ag}$ 함량 0.3-3.0 wt\% 사이에서는 $\mathrm{Sn}-\mathrm{Ag}-\mathrm{Cu}$ 솔더의 초기 접합강도에 미치 는 영향이 동등한 수준으로 판단된다.

4) $\mathrm{ENEPIG}$ 표면처리 기판과 $\mathrm{SAC}$ 솔더 접합부 접합계 면에는 $\mathrm{Cu}_{6} \mathrm{Sn}_{5}, \mathrm{Ag}_{3} \mathrm{Sn}, \quad(\mathrm{Ni}, \mathrm{Cu}, \mathrm{Pd})_{3} \mathrm{Sn}_{4}\left(\mathrm{Cu}, \mathrm{Ni}_{6} \mathrm{Sn}_{5}\right.$, $\mathrm{NiP}, \mathrm{Ni}_{3} \mathrm{P} \mathrm{IMC}$ 등 다양한 종류의 $\mathrm{IMC}$ 가 형성되었 으며, 이러한 $\mathrm{IMC}$ 는 솔더 접합부 초기 접합강도 향상 에 기여하는 것으로 판단된다.

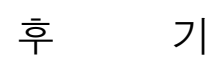

본 연구는 산업통상자원부에서 지원한 소재부품기술 개발사업 (과제번호: 20011427)의 지원으로 수행된 연구결과입니다.

ORCID: Won Sik Hong: http://orcid.org/0000-0001-8398-177X ORCID: Mi-Song Kim: https://orcid.org/0000-0002-4717-9365 ORCID: Myeongin Kim: https://orcid.org/0000-0002-5151-1404

\section{References}

1. S. J. Kim, W. S. Hong, H. B. Nam, and N. H. Kang, Growth Behavior of Intermetallic Compounds in Various Solder Joints Induced by Electromigration, J. Weld. 
Join. 39(1) (2021) 89-102.

https://doi.org/10.5781/JWJ.2021.39.1.11

2. G. T. Kim, G. H. Kang, and D. I. Kwon, Effect of Material Property Uncertainty on Warpage during Fan Out Wafer-Level Packaging Process, J. Microelectron. Packag. Soc. 26(1) (2019) 29-33. https://doi.org/10.6117/kmeps.2019.26.1.0029

3. C. I. Chen, C. Y. Ni, C. M. Chang, S. C. Wu, and D. S. Liu, Bondability Study of Chip-on-Film (COF) Inner Lead Bonding (ILB) Using Conventional Gang Bonder, IEEE Trans. Electro. Packag. Manuf. 31(4) (2008) 285-290.

4. W. S. Hong and C. M. Oh, PoF Based Accelerated Life Prediction with 3 Dimensional Packaging Technology Development, J. Korean Weld. Join. Soc. 27(3) (2009) 10-16.

5. W. S. Hong, S. B. Jung, and K. B. Kim, Analysis Method of Metallic Ion Migration, J. Korean Weld. Join. Soc. 23(2) (2005) 32-406.

6. Interactive User Guide, Multilayer Ceramic Capacitor, Samsum Electo-Mechanics Co, Ltd., Accessed on http://product.samsungsem.com/mlcc, $8^{\text {th }}$ July 2021.

7. Won Sik Hong and Chul Min Oh, Thermal Shock Reliability of Low Ag Composition $\mathrm{Sn}-0.3 \mathrm{Ag}-0.7 \mathrm{Cu}$ and Near Eutectic Sn-3.0Ag-0.5Cu Pb-free Solder Joints, J. Korean Inst. Met. Mater. 47(12) (2009) 842-851.
8. W. S. Hong, W. S. Kim, B. S. Song, and K. B. Kim, Thermal Shock Cycles Optimization of Sn-3.0 Ag-0.5 $\mathrm{Cu} / \mathrm{OSP}$ Solder Joint with Bonding Strength Variation for Electronic Components, Korean J. Mater. Res. 17(3) (2007) 152-159.

9. D. W. Suh, D. W. Kim, P. Liu, H. C. Kim, J. A. Weninger, C. M. Kumar, A. Prasad, B. W. Grimsley, and H. B. Tejada, Effects of Ag Content on Fracture Resistance of $\mathrm{Sn}-\mathrm{Ag}-\mathrm{Cu}$ Lead-Free Solders under High-Strain Rate Conditions, Mater. Sci. Eng. A. 460 (461) (2007) 595-603.

10. J. H. Back, B. S. Lee, S. H. Yoo, D. G. Han, S. B. Jung, and J. W. Yoon, Solderability of Thin ENEPIG Plating Layer for Fine Pitch Package application, $J$. Microelectron. Packag. Soc. 24(1) (2017) 83-90. https://doi.org/10.6117/kmeps.2017.24.1.083

11. J. Y. Park, M. S. Kim, C. M. Oh, S. H. Do, J. D. Seo, D. K. Kim, and W. S. Hong, Solder Joint Fatigue Life of Flexible Impact Sensor Module for Automotive Electronics, Korean J. Met. Mater. 55(4) (2017) 232-239. https://doi.org/10.3365/KJMM.2017.55.4.232

12. W. Liu, Y. Tian, C. Wang, and L. Sun, Formation of AuSnx IMCs in Sn3.5Ag0.75Cu Micro-Solder Joints Fabricated by Laser and Hot Air Reflow Processes, $J$. Mater. Sci. Mater. Electron. 24(1) (2012) 1-7. https://doi.org/10.1007/s10854-012-0715-8 